\title{
Zinc oxide nanoparticles exhibit cytotoxicity and genotoxicity through oxidative stress responses in human lung fibroblasts and Drosophila melanogaster
}

This article was published in the following Dove Press journal:

International Journal of Nanomedicine

28 February 2017

Number of times this article has been viewed

\author{
Cheng Teng $\mathrm{Ng}^{1,2, *}$ \\ Liang Qing Yong ${ }^{1, *}$ \\ Manoor Prakash Hande ${ }^{3}$ \\ Choon Nam Ong² \\ Liya $\mathrm{E} \mathrm{Yu}^{4}$ \\ Boon Huat Bay' \\ Gyeong Hun Baeg'
}

'Department of Anatomy, Yong Loo Lin School of Medicine, National

University of Singapore, Singapore;

${ }^{2}$ Environmental Research Institute,

National University of Singapore,

Singapore; ${ }^{3}$ Department of

Physiology, Yong Loo Lin School of

Medicine, ${ }^{4}$ Department of Civil and

Environmental Engineering, National

University of Singapore, Singapore,

Singapore

*These authors contributed equally to this work

\begin{abstract}
Background: Although zinc oxide nanoparticles ( $\mathrm{ZnO}$ NPs) have been widely used, there has been an increasing number of reports on the toxicity of ZnO NPs. However, study on the underlying mechanisms under in vivo conditions is insufficient.

Methods: In this study, we investigated the toxicological profiles of ZnO NPs in MRC5 human lung fibroblasts in vitro and in an in vivo model using the fruit fly Drosophila melanogaster. A comprehensive study was conducted to evaluate the uptake, cytotoxicity, reactive oxygen species (ROS) formation, gene expression profiling and genotoxicity induced by ZnO NPs.

Results: For in vitro toxicity, the results showed that there was a significant release of extracellular lactate dehydrogenase and decreased cell viability in ZnO NP-treated MRC5 lung cells, indicating cellular damage and cytotoxicity. Generation of ROS was observed to be related to significant expression of DNA Damage Inducible Transcript (DDIT3) and endoplasmic reticulum (ER) to nucleus signaling 1 (ERNI) genes, which are ER stress-related genes. Oxidative stress induced DNA damage was further verified by a significant release of DNA oxidation product, 8-hydroxydeoxyguanosine (8-OHdG), as well as by the Comet assay. For the in vivo study using the fruit fly $D$. melanogaster as a model, significant toxicity was observed in F1 progenies upon ingestion of ZnO NPs. ZnO NPs induced significant decrease in the egg-to-adult viability of the flies. We further showed that the decreased viability is closely associated with ROS induction by ZnO NPs. Removal of one copy of the D. melanogaster Nrf 2 alleles further decreased the $\mathrm{ZnO}$ NPs-induced lethality due to increased production of ROS, indicating that nuclear factor E2-related factor 2 ( Nrf2) plays important role in ZnO NPs-mediated ROS production.

Conclusion: The present study suggests that $\mathrm{ZnO}$ NPs induced significant oxidative stressrelated cytotoxicity and genotoxicity in human lung fibroblasts in vitro and in D. melanogaster in vivo. More extensive studies would be needed to verify the safety issues related to increased usage of $\mathrm{ZnO}$ NPs by consumers.
\end{abstract}

Keywords: zinc oxide nanoparticles, ROS, oxidative stress, MRC5 cells, Drosophila

\section{Introduction}

Nanotechnology is an interdisciplinary platform, where a broad range of nanosize materials is being developed for novel and innovative applications. Nanomaterials possess properties that are not found in the bulk form, thereby, giving the nanomaterials new and enhanced physicochemical and biological properties, as well as functionalities. ${ }^{1}$ Nanotechnology has provided a wide variety of products for the industrial, food packaging, agricultural, consumer and medical sectors. It has been estimated that the global market value of nanotechnology-associated products would continue to evolve and reach a market value of over US\$20 billion by $2020 .^{2-4}$
Correspondence: Gyeong Hun Baeg Department of Anatomy, Yong Loo Lin School of Medicine, National University of Singapore, 4 Medical Drive, Singapore 117597, Singapore

Tel +65 65167973

Email antbgh@nus.edu.sg 
$\mathrm{Zn}$, a group II-VI semiconductor and versatile inorganic compound, is an essential component of the human diet. Having an adequate amount of $\mathrm{Zn}$ in the body is crucial for the protein and DNA synthesis, optimal functioning of immune response, retinal development, blood clotting, liver function, metalloenzyme function and olfaction. ${ }^{5}$ On top of its great chemical sensing and electric conductivity, $\mathrm{ZnO}$ NPs possess ultraviolet scattering and antimicrobial (both antibacterial and antifungal) properties. Their bactericidal values are useful for biomedical applications and food packaging. ${ }^{6,7}$ Moreover, $\mathrm{ZnO} \mathrm{NP}$ usage has extended its reach into consumers in the form of cosmetics and textiles, and the industrial setting in the form of electronic products. Zn nanomaterials are also being used as a catalyst in automobile tail gas treatment. ${ }^{8}$

However, the emergence of $\mathrm{ZnO}$ NP-based products has raised concerns regarding their potential toxicity and safety due to the increased exposure. Several in vitro studies have demonstrated the undesirable toxic effects of ZnO NPs, such as the induction of oxidative stress, autophagic cell death, inflammatory responses, cellular damage and genotoxicity. ${ }^{9-13}$ The toxicity of $\mathrm{ZnO}$ NPs has been shown to be attributed to the dissolution of $\mathrm{Zn}$ to free $\mathrm{Zn}^{2+}$ ions and the generation of free radicals from the surface of $\mathrm{ZnO}$, resulting in cellular ionic and metabolic imbalance that is associated with a defect in ionic homeostasis and an inhibition of ion transport. ${ }^{9,12,14,15}$ In vitro toxicity studies revealed that generation of reactive oxygen species (ROS), followed by ROS-induced oxidative stress, is the mechanism leading to the $\mathrm{ZnO}$ NP-mediated toxicity. Insufficient antioxidative protective mechanism following excessive ROS production, has shown to elicit cell death and genotoxicity. ${ }^{14}$ Other than the inherent properties of ZnO NPs, physicochemical properties, such as size and surface charges contribute to the toxicity of ZnO NPs. In addition to the phase (amorphous, anatase, etc) and contact area between a single nanoparticle (NP) and a single cell, smaller and rod shaped nano $\mathrm{ZnO}$ (in comparison to spherical shape) is reported to be more toxic. ${ }^{15-17}$ The surface charge of NPs is also an important factor in considering the toxicity, as the positively charged NPs were shown to possess a higher toxicity, ${ }^{9}$ and differential surface charge is attributed to the cellular uptake and intracellular localization. ${ }^{18}$ The toxic effects of in vivo exposure have been reported in vertebrates such as rodent ${ }^{6}$ and zebra fish, ${ }^{19,20}$ as well as the invertebrate the fruit fly Drosophila melanogaster. ${ }^{21}$

The generation of free radicals is known to cause oxidative damages in DNA and subsequently produce the product 8-hydroxy-2'-deoxyguanosine (8-OHdG), an established oxidative DNA damage marker. ${ }^{22} \mathrm{An}$ in vitro study demonstrated that $\mathrm{ZnO} N P s$ ( $\leq 35$ or $50-80 \mathrm{~nm}$ ) are able to cause oxidative
DNA damage and genotoxicity as revealed by the Comet assay in human lymphoblastoid cells. ${ }^{23}$ Other studies using mammalian cultured cells have also shown the potential risk of $\mathrm{ZnO}$ NPs in the induction of genotoxicity. ${ }^{24-26}$ Although oxidative stress has been proposed as the main mechanism responsible for the toxicity of NPs, the direct role of ROS-associated genes in the toxicity remains to be explored. Despite of these toxicity studies, the hazardous effects of ZnO NPs still remain debatable. ${ }^{27}$ Studies reported that $\mathrm{ZnO}$ NPs cause no toxicity to human cells and only low subchronic toxicity to rodents. ${ }^{28-30}$ Furthermore, a previous study using Drosophila had reported no toxicity observed upon the ingestion of $\mathrm{ZnO}$ NPs. ${ }^{21}$ On the other hand, another earlier study assessing the genotoxicity and oxidative stress induced by $\mathrm{ZnO}$ NPs in Drosophila showed a weak genotoxicity of ZnO NPs. ${ }^{31}$

The human lungs remain a vulnerable organ for NP invasion where the respiratory tract is considered the primary target for inhaled NPs. ${ }^{32}$ Therefore, the cytotoxic effects of $\mathrm{ZnO}$ NPs were comprehensively evaluated using various cellular assays, including lactate dehydrogenase (LDH), AlamarBlue assay and flow cytometry (fluorescence-activated cell sorting [FACS]) in the human lung fibroblast MRC5 cell line. ROS generation was monitored by the 6-carboxy$2^{\prime}, 7^{\prime}$-dichlorodihydro fluorescein diacetate (DCFDA) assay, as well as by the gene expression profiling of a panel of endoplasmic reticulum (ER) stress genes (XBP1, DDIT3, TRIB3, ADM2, HSPA5, CASP12, ASNS, HERPUD1, ERN1, EIF2AK3 and ATF6) in the MRC5 cells. The 8-OHdG was used for the evaluation of oxidative stress with the use of enzyme-linked immunosorbent assay and comet assays to assess genotoxicity. For the in vivo study, wild-type adult flies were fed with $\mathrm{ZnO}$ NPs at different doses, and the egg-to-adult survival of $\mathrm{F} 1$ progenies was recorded. In an attempt to determine if the decrease in viability was mediated through $\mathrm{ZnO} N \mathrm{NP}$-induced ROS, we tested the inhibitory effects of Nrf2, which is the key molecule involved in the expression of detoxifying and antioxidant enzymes in response to oxidative stress, and found that the removal of one copy of $\mathrm{Nrf} 2$ further decreased $\mathrm{ZnO}$ NP-mediated viability. This is the first genetic study indicating that ROS production is one of the direct causes of $\mathrm{ZnO}$ NP-mediated toxicity in the fruit fly Drosophila.

\section{Materials and methods Materials}

ZnO NPs (product number 721077 from Sigma-Aldrich) of $<100 \mathrm{~nm}$ particle size (by dynamic light scattering [DLS]) were used in this study. ZnO NPs were prepared in Milli-Q water for hydrodynamic size analysis by DLS. The stock concentration of $1 \mathrm{mg} / \mathrm{mL}$ solution was prepared freshly, 
sonicated and sterile filtered before using for experimentation. To examine the effects of $\mathrm{ZnO}$ NPs in different sizes on toxicity, $\mathrm{ZnO}$ NPs $(\sim 50-80 \mathrm{~nm}$ particle size in aqueous dispersion; US Research Nanomaterials, Inc.) were also used for comparison.

\section{Characterization of $\mathrm{ZnO}$ NPs}

Transmission electron microscopy (TEM) analysis for the materials was performed using the JEOL 1010 TEM. The NanoDrop ${ }^{\circledR}$ ND-1000 UV-Vis Spectrophotometer (NanoDrop Technologies Inc., USA) was used to analyze the absorption spectrum of ZnO NPs. In addition, DLS and zeta potential (Zetasizer Nano ZS, Worcestershire, UK) were measured to assess the hydrodynamic size and surface charge of $\mathrm{ZnO}$ NPs in solution.

\section{Cell culture}

Human MRC5 fetal lung fibroblasts (ATCC ${ }^{\circledR}$ CCL-171 ${ }^{\mathrm{TM}}$ ) that are between passage 20 and 30 were cultured in Roswell Park Memorial Institute (RPMI 1640) supplemented with 10\% heat-inactivated fetal bovine serum (FBS), together with 100 $\mu \mathrm{g} / \mathrm{mL}$ streptomycin and $100 \mathrm{units} / \mathrm{mL}$ penicillin. The cells were maintained in a cell culture incubator (Thermo Electron Corporation, Madison, WI, USA) with humidified atmosphere of $37^{\circ} \mathrm{C}$ and $5 \% \mathrm{CO}_{2}: 95 \% \mathrm{O}_{2}$, before passaging. The morphology of cells was examined under the Nikon Eclipse TS100 microscope (Nikon Corporation, Tokyo, Japan) attached with a Digital Sight DS-U1 camera. The setup was also equipped with the ACT-2U imaging software version 1.60.

\section{$\mathrm{ZnO}$ NP treatment in vitro}

As-synthesized $\mathrm{ZnO}$ NPs were used to prepare a range of concentrations $(0,1,10,25,50,75$ and $100 \mu \mathrm{g} / \mathrm{mL})$ from $1 \mathrm{mg} / \mathrm{mL}$ of ZnO NP stock solution, for treating the cells for 24, 48 and 72 h. Lipoic acid (LA) and glutathione (GSH) (Sigma, St Louis, MO, USA) at $300 \mu \mathrm{M}$ and $3 \mathrm{mM}$, respectively, were added $24 \mathrm{~h}$ before $\mathrm{ZnO} N \mathrm{NP}$ treatment to examine the effect of antioxidant on $\mathrm{ZnO}$ NP-induced cytotoxicity.

\section{TEM}

MRC5 fibroblasts were treated with $\mathrm{ZnO}$ NPs and cultured in LabTeck culture chambers for TEM sample preparation. Cells were then fixed in $2.5 \%$ glutaraldehyde (GA) for $1 \mathrm{~h}$ before rinsing 3 times with phosphate-buffered saline (PBS) at the time interval of 5 min each. Samples were osmified with $1 \% \mathrm{OsO}_{4}$ and bits of $\mathrm{KFeCN}$ (Agar Scientific Ltd, Stansted, UK) at room temperature for $1 \mathrm{~h}$. Subsequently, samples were dehydrated by immersing in a graded series of ethyl alcohol for 10 min each and embedded in epoxy resin (polymerization at $60^{\circ} \mathrm{C}$ for overnight) (Ted Pella Inc., CA, USA). This was followed by slicing of ultrathin sections, which were then mounted on formvar-coated $\mathrm{Cu}$ grids. Sections were stained with lead citrate (BDH, Bristol, UK). Digital micrographs were obtained using a Gatan 792 Bioscan $1 \mathrm{k} \times 1 \mathrm{k}$ Wide Angle Multiscan charge-coupled device camera attached to the JEOL 1010 TEM.

To detect the presence of $\mathrm{ZnO}$ NPs in the intestine of the Drosophila larvae, the midguts of control and $\mathrm{ZnO}$ NPtreated third instar larvae were dissected out and collected in PBS, before fixation in 2.5\% GA. Subsequent processing steps for TEM are as described earlier.

\section{Acridine orange and ethidium bromide $(\mathrm{AO} / \mathrm{EtBr})$ staining}

About $1 \mathrm{mg} / \mathrm{mL} \mathrm{AO}$ and $\mathrm{EtBr}$ were constituted from the powder form with PBS. For discrimination of live from dead cells, AO fluoresces as green color, indicating live viable cells; EtBr fluoresces as orange color when intercalated with DNA, representing dead cells. The medium was first removed from $\mathrm{ZnO}$ NP-treated cells. Stock solution was further diluted $100 \times$ with PBS to a working concentration before adding into the cells. Diluted dyes were added for 1 min at room temperature, removed and washed with PBS before micrographs were taken.

\section{LDH assay}

Cells were seeded into a 96 -well plate for $24 \mathrm{~h}$. Subsequently, the medium was aspirated and replaced with $200 \mu \mathrm{L}$ of medium containing $0,1,10,25,50,75$ and $100 \mu \mathrm{g} / \mathrm{mL}$ of $\mathrm{ZnO}$ NPs into each well. After 24, 48 and $72 \mathrm{~h}$ incubation, $100 \mu \mathrm{L}$ of supernatant was sampled and transferred to a new plate. One hundred microliters of reaction mixture (consisting of a catalyst and dye solution) was then added. Following 30 min of incubation at room temperature, the LDH activity in the supernatant was quantified using a SpectraMax M5 MicroPlate reader at $490 \mathrm{~nm}$ wavelength.

\section{AlamarBlue ${ }^{\circledR}$ assay}

The cytotoxicity of $\mathrm{ZnO}$ NP-treated MRC5 fibroblasts was monitored by the AlamarBlue assay. Briefly, MRC5 fibroblasts (seeded at $8 \times 10^{3}$ cells/well) were treated with $\mathrm{ZnO} \mathrm{NPs}$ at various doses for 24-72 $\mathrm{h}$ in 96-well plates. After removal of existing medium, 1/10th volume of AlamarBlue reagent (Thermo Fisher Scientific) was added directly to the cells in the culture medium and incubated for $2 \mathrm{~h}$ at $37^{\circ} \mathrm{C}$ (protected from direct light). Fluorescence reading was recorded (excitation wavelength of $570 \mathrm{~nm}$; emission wavelength $585 \mathrm{~nm}$ ) using the same microplate reader. 


\section{FACS analysis}

Cells were plated onto 6-well culture plates, and then $\mathrm{ZnO}$ NP treatment was performed for 16 and $24 \mathrm{~h}$. After each time point, cells were collected into a $15 \mathrm{~mL}$ centrifuge tube and pelleted by centrifugation at 1,000 rpm for $5 \mathrm{~min}$. Cell pellets were washed twice with PBS, and subsequently cells were stained using Annexin V and fluorescein isothiocyanate (FITC) Apoptosis Detection Kit I (BD Biosciences). Briefly, cells were resuspended with $1 \times$ binding buffer at a concentration of $1 \times 10^{5}$ cells per $100 \mu \mathrm{L}$. Five microliters of FITC Annexin $\mathrm{V}$ and $5 \mu \mathrm{L}$ propidium iodide (PI) were added and incubated for $15 \mathrm{~min}$ at room temperature $\left(25^{\circ} \mathrm{C}\right)$ away from light. Samples were top up with another $400 \mu \mathrm{L}$ of $1 \times$ binding buffer before analyzing by flow cytometry.

For cell cycle analysis, the cell pellet was fixed with ice cold ethanol overnight. The cells were washed and permeabilized with Triton-X 100, and then stained with PI. Samples were kept in the dark before being analyzed. A total of $1 \times 10^{4}$ events for each sample were analyzed and scored by Dako Cyan flow cytometer (DakoCytomation) supplemented with the Summit ${ }^{\mathrm{TM}}$ software.

\section{Cellular ROS detection assay}

ZnO NP-treated and NP-untreated cells were stained with DCFDA for $30 \mathrm{~min}$ at $37^{\circ} \mathrm{C}$. Cells were then washed and incubated with cell culture medium before measuring the fluorescence intensity by FACS.

\section{RNA extraction, reverse transcription (RT) and quantitative real-time RT- polymerase chain reaction ( $q R T-P C R$ )}

The Purelink RNA Mini Kit (Thermo Fisher Scientific) was used to isolate total RNA. RNA quality was assessed using the NanoDrop ND-1000 Spectrophotometer at the absorbance reading of 260 and $280 \mathrm{~nm}$ wavelengths. MRC5 cells were lysed, followed by the addition of an equal volume of $70 \%$ ethanol. Samples were then transferred into a Spin Column and centrifuged for $15 \mathrm{~s}$ at 13,200 rpm. After which, samples were subjected to washing steps using the buffers provided inside the kit and spun dry to remove excessive ethanol, followed by elution with RNase-free water.

For cDNA conversion, Agilent AffinityScript qPCR cDNA synthesis kit (Genomax Technologies) was used according to manufacturer's instructions. cDNA was stored at $-20^{\circ} \mathrm{C}$ for later use. A mixture consisting of diluted cDNA, SYBR Green PCR Master Mix (Thermo Fisher Scientific) and primer for each gene was analyzed by a 7900HT Fast RealTime PCR machine (Thermo Fisher Scientific) following the thermal profile settings: $95^{\circ} \mathrm{C}, 20 \mathrm{~s} ; 95^{\circ} \mathrm{C}, 1 \mathrm{~s}$ followed by $60^{\circ} \mathrm{C}, 20 \mathrm{~s}$ for 40 cycles. The fold change in expression for each gene of the samples was calculated.

\section{8-OHdG DNA damage quantification}

EpiQuik $^{\mathrm{TM}}$ 8-OHdG DNA damage quantification kit (Epigentek) was used to monitor oxidative DNA damage. DNA from ZnO NP-treated MRC5 cells was extracted using PureLink ${ }^{\circledR}$ Genomic DNA Mini Kit (Thermo Fisher Scientific). First, binding solution was added prior to adding the DNA samples. After incubation at $37^{\circ} \mathrm{C}$ for $90 \mathrm{~min}$, the binding solution was removed and washed three times with washing buffer. Next, capture antibody was added, incubated for $60 \mathrm{~min}$ and removed before washing steps. The detection antibody was then added and incubated for $30 \mathrm{~min}$, and washed before adding the enhancer solution. Wells were washed five times before the developer solution was introduced. After sufficient color development was observed in the positive control set, the reaction was stopped by adding the stop solution. The absorbance was taken at $450 \mathrm{~nm}$.

\section{Comet assay}

ZnO NP-treated MRC5 cells were mixed with low melting agarose before embedding on the comet slide. The cells were lysed in prechilled lysis buffer for an hour, followed by denaturation in alkaline running buffer. The comet slide was then placed on a horizontal electrophoresis tank, run at $25 \mathrm{~V}$ for $20 \mathrm{~min}$. Cells were placed inside neutralizing buffer before subjected to dehydration with $70 \%$ ethanol. Dried cells were stained with SYBR Green before viewing under Zeiss Axioplan 2 imaging fluorescence microscope equipped with the CometImager software.

\section{Fly strains}

The following D. melanogaster strains were used in this study: the wild-type Canton-S; Sod2 $2^{\mathrm{N3} 308} / \mathrm{CyO}$ (obtained from NIG-FLY); and $c n c C^{K 6} / T M 3$, $S b$ (a gift from Dr Kerppola T). ${ }^{33}$ For in vivo viability assay, wild-type adult flies were placed in vials containing food media supplemented with either 0 , $0.1,0.25,0.5$ and $1 \mathrm{mg} / \mathrm{mL} \mathrm{ZnO}$ NPs. The parent flies were then removed after 5 days, and the viability of the laid eggs to adult stage was monitored. Emerged F1 (1st filial or generation) flies were collected and counted, and the percentage of viability as compared with the control (nontreated; $0 \mathrm{mg} \mathrm{ZnO}$ $\mathrm{NPs}$ ) was calculated. To assess whether inhibition of $\mathrm{CncC}$ (the Drosophila homolog of Nrf2) or superoxide dismutase 2 (SOD2) activity can further increase $\mathrm{ZnO}$ NP-induced ROS and thus decrease the ZnO NP-induced viability, 
virgin female $c n c C^{K 6} / T M 3$, Sb or $S o d 2^{N 308} / C y O$ flies were crossed with male Canton-S flies. Flies were transferred to food media containing $0,0.25$ or $0.5 \mathrm{mg} / \mathrm{mL} \mathrm{ZnO} \mathrm{NPs}$. Emerged adults were collected and counted, and the percentage of viability with respect to the control (balanced flies) was calculated.

\section{ROS detection using dihydroethidium (DHE) staining}

Larvae treated with $\mathrm{ZnO}$ NPs at different concentrations are collected and placed in PBS in dissection glass plates at room temperature. The guts of the larvae were dissected and incubated in Schneider's Drosophila medium for optimal respiration. One microliter of the DHE dye (stock concentration of $30 \mathrm{mM}$ ) was dissolved in $1 \mathrm{~mL}$ of Schneider's medium, giving a final concentration of $30 \mu \mathrm{M}$. The gut tissues were incubated for $5 \mathrm{~min}$ in dark at room temperature, before washing thrice with medium at $5 \mathrm{~min}$ interval. Lastly, the tissues were mounted onto glass slides in Vectashield with 4',6-diamidino-2-phenylindole (DAPI) before capturing images with a confocal microscope.

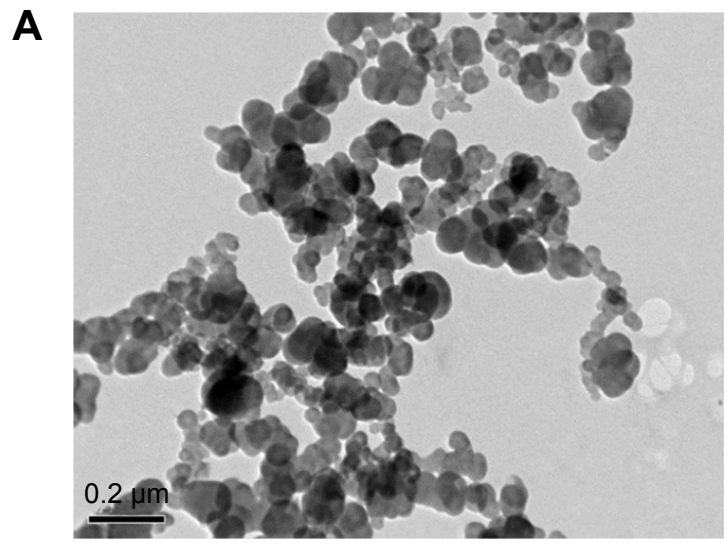

C

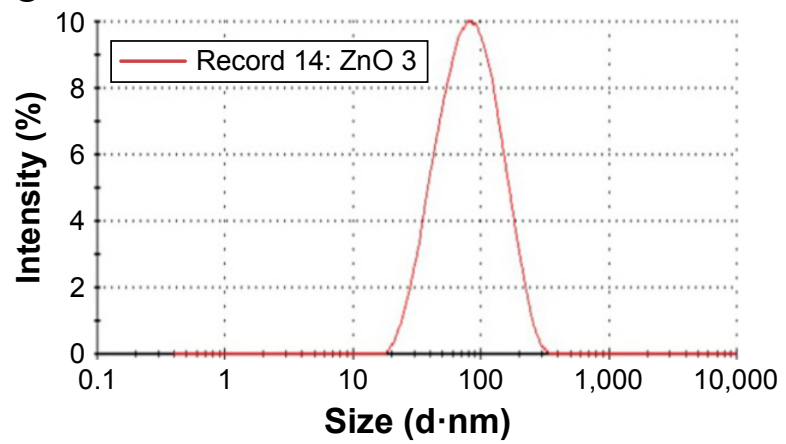

\section{Statistical analysis}

Statistical calculations were performed using the Graph Pad Prism Version 6.0 (GraphPad Software, CA, USA). Data were presented as mean values \pm standard error of the mean (SEM) from triplicates $(\mathrm{n}=3)$. Student's $t$-test was used to analyze differences between two groups; while One Way analysis of variance with post hoc test (Tukey's Multiple Comparison Test) was used if there were three or more groups of data involved for comparison. $* P<0.05, * * P<0.01$, $* * * P<0.001$ and $* * * * P<0.0001$ were considered statistically significant.

\section{Results \\ ZnO NPs physicochemical properties}

The physicocharacteristics of ZnO NPs were determined prior to the start of the biological part of the study. TEM images showed that the ZnO NPs are spherical in shape, with an average hydrodynamic size of $\sim 70 \mathrm{~nm}$ in diameter in suspension (Figure 1A and $\mathrm{C}$ ) and have an absorption peak at $360 \mathrm{~nm}$ (Figure 1B). The surface charge of ZnO NPs was $+5.8 \mathrm{mV}$ (Figure 1D). Agglomeration of $\mathrm{ZnO}$ NPs was

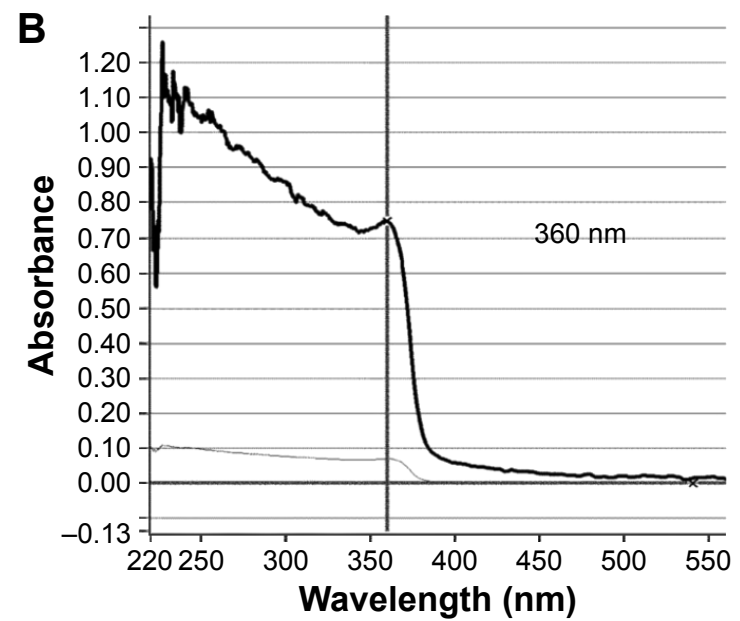

D

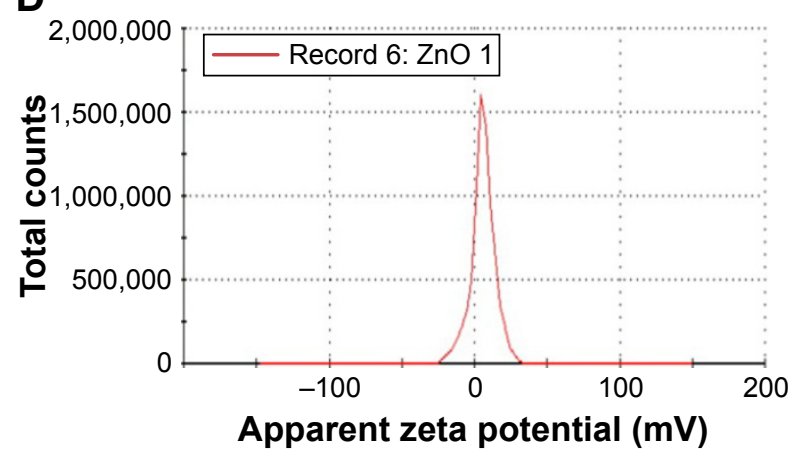

Figure I Characterization of ZnO NPs.

Notes: (A) A representative TEM micrograph of ZnO NPs. (B) UV-vis of ZnO NPs reveals an absorption peak at $360 \mathrm{~nm}$. (C) Size distribution of ZnO NPs from DLS. ZnO $\mathrm{NPs}$ are $\sim 70 \mathrm{~nm}$ in diameter in solution. (D) Zeta potential of ZnO NPs is $+5.8 \mathrm{mV}$.

Abbreviations: DLS, dynamic light scattering; NPs, nanoparticles; TEM, transmission electron microscopy; UV-vis, ultraviolet-visible. 
observed by TEM, suggesting the high value for the hydrodynamic radius and the low zeta potential observed. $\mathrm{ZnO}$ NPs had a wide distribution with polydispersity index $>0.1$ before sonication. Hence, freshly sonicated $\mathrm{ZnO}$ NP dispersions were used immediately for treatment purpose.

\section{Exposure to $\mathrm{ZnO}$ NPs shows a dose- dependent cytotoxicity in the human lung MRC5 cells}

We first confirmed the uptake and internalization of $\mathrm{ZnO}$ NPs into the human lung MRC5 cells by performing TEM study. ZnO NPs were detected in the cytoplasm of the cells in the form of electron dense clusters, which are found to be enclosed by vesicles, whereas $\mathrm{ZnO}$ NPs were not observed in untreated control cells (Figure 2A and B). We next examined the cytotoxicity of $\mathrm{ZnO}$ NPs at various concentrations in MRC5 cells. A significant morphological change in $\mathrm{ZnO}$ NP-treated MRC5 cells was observed under the light microscope, compared to control cells (Figure 2C and D). While ZnO NP-treated MRC5 cells showed cell shrinkage, nuclear changes and the formation of apoptotic body under fluorescence microscopic examination using $\mathrm{AO} / \mathrm{EtBr}$
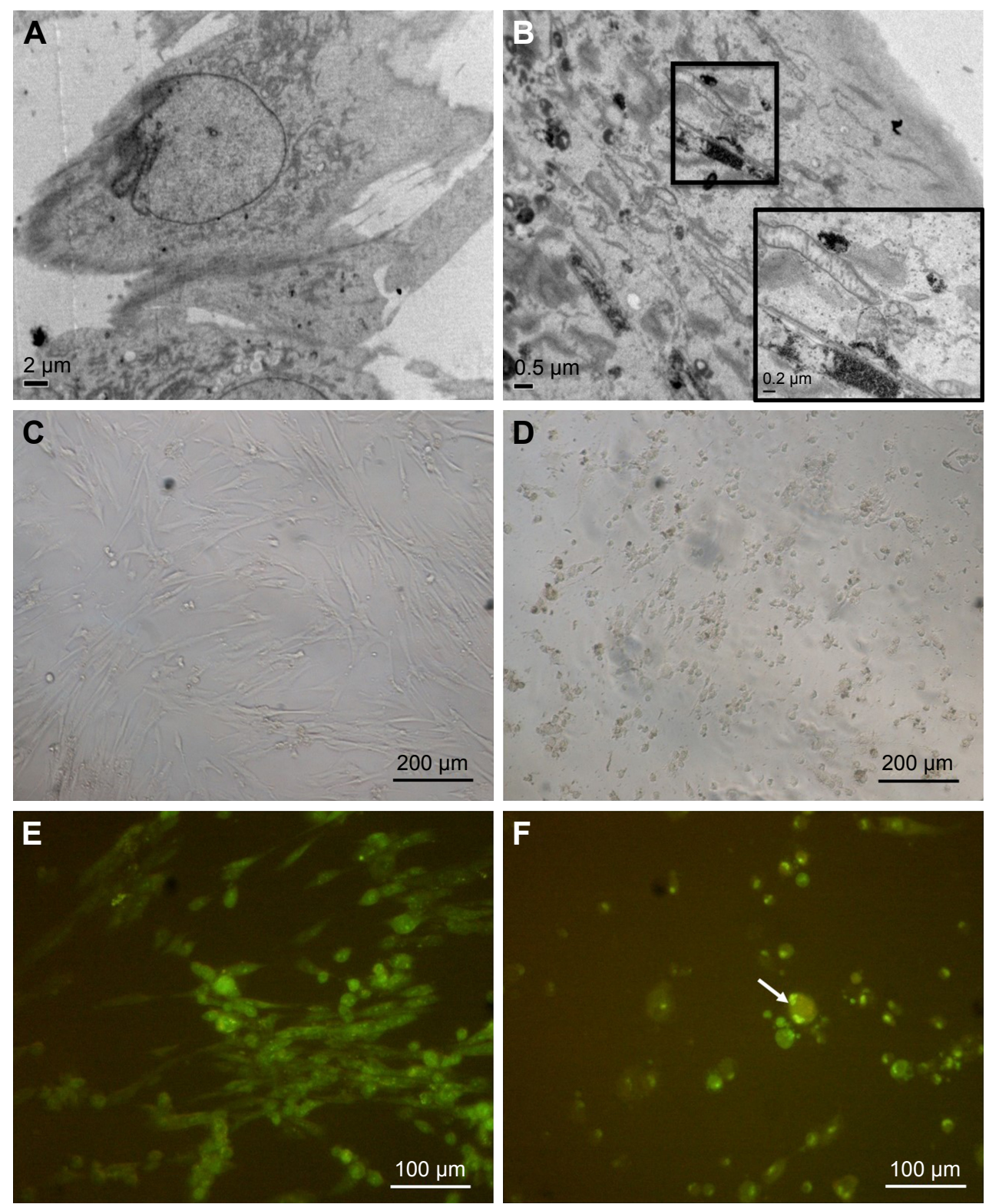

Figure 2 Cellular uptake of $\mathrm{ZnO}$ NPs and morphological changes in treated human MRC5 lung fibroblasts.

Notes: (A) EM micrograph of untreated MRC5 lung fibroblast. (B) EM micrograph of ZnO NP-treated MRC5 lung fibroblast. (C) LM micrograph of untreated MRC5 lung fibroblast. Magnification: $\times 100$. (D) LM micrograph of $50 \mu \mathrm{g} / \mathrm{mL} \mathrm{ZnO} \mathrm{NP-treated} \mathrm{cells.} \mathrm{Cells} \mathrm{are} \mathrm{shrunken,} \mathrm{indicative} \mathrm{of} \mathrm{cell} \mathrm{death.} \mathrm{Magnification:} \times$ I00. (E) Confocal micrograph of untreated MRC5 cell. Magnification: $\times 200$. (F) Confocal micrograph of cells treated with $25 \mu \mathrm{g} / \mathrm{mL}$ ZnO NPs, showing cell shrinkage (as indicated by arrow). Magnification: $\times 200$. Abbreviations: EM, electron microscope; NPs, nanoparticles; LM, light microscope. 
staining, untreated cells did not exhibit any alterations in cell morphology (Figure 2E and F).

Furthermore, we found that $\mathrm{ZnO}$ NP-treated MRC5 cells, which have lost their membrane integrity, were associated with the release of LDH in a dose-dependent manner, indicating that $50 \mu \mathrm{g} / \mathrm{mL} \mathrm{ZnO} \mathrm{NP}$ exposure can cause cell death (Figure 3A). Cell viability was consistently found to be significantly decreased as early as $24 \mathrm{~h}$ after treatment, and $\mathrm{ZnO} N$ Ps at a concentration of $50 \mu \mathrm{g} / \mathrm{mL}(617 \mu \mathrm{M})$ caused total cell death (Figure 3B). There was also a decrease in cell proliferation as revealed by the cell cycle analysis, which showed a significant decrease in the total DNA content of treated cells at both $\mathrm{S}$ and G2/M phases, as compared to control. Consistent with the inhibitory effect of ZnO NPs on cell growth, cells in sub-G1 phase significantly increased, suggesting an occurrence of cell death upon $\mathrm{ZnO} N \mathrm{NP}$ treatment (Figure 3C). Since ZnO NP-treated cells showed abnormal cell morphology in the fluorescence microscopic examination using $\mathrm{AO} / \mathrm{EtBr}$ staining and in the cell cycle analysis, we next verified that $\mathrm{ZnO} N P s$ can induce apoptosis. We carried out FACS analyses using FITC/PI-stained MRC5 cells, and found that $\mathrm{ZnO}$ NP treatment indeed resulted in apoptotic cell death (Figure 3D).

\section{Exposure to ZnO NPs causes ROS induction and increases the expression of genes associated with ER stress in MRC5 fibroblasts}

A growing body of evidence indicates that ROS play essential roles in NP-mediated toxicity. ${ }^{34,35} \mathrm{We}$ thus reasoned that $\mathrm{ZnO}$ NP-mediated toxicity in MRC5 fibroblasts is caused by oxidative stress. Hence, we evaluated the oxidative stress induced by $\mathrm{ZnO}$ NP exposure by performing DCFDA staining, followed by flow cytometry to monitor the cellular
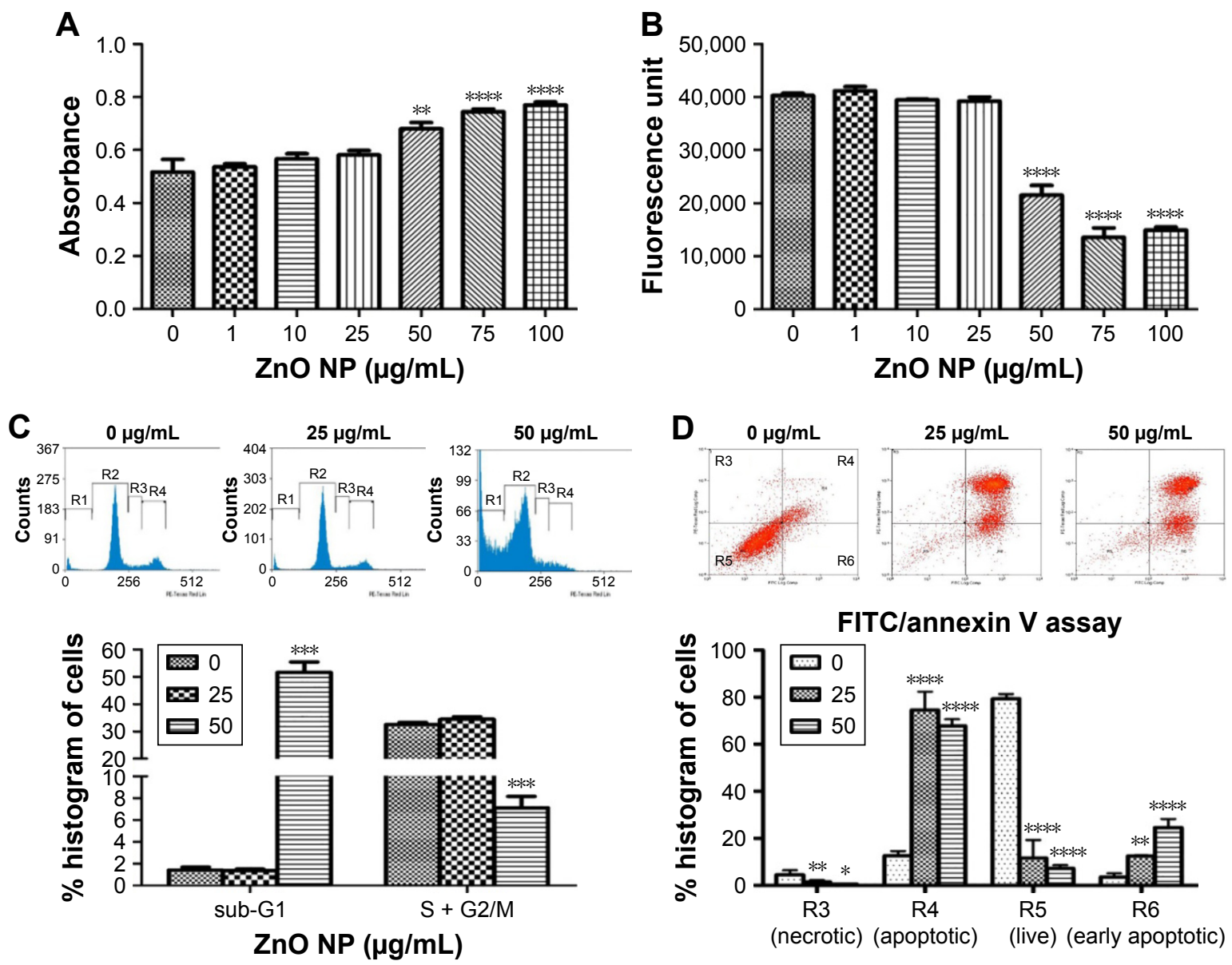

Figure $3 \mathrm{ZnO}$ NP exposure caused decrease in cell survival and proliferation in MRC5 cells.

Notes: (A) LDH assay reveals early cytotoxicity of $\mathrm{ZnO} N P s$ on MRC5 cells. MRC5 cells release significant amount of LDH into the culture media, indicating cellular membrane disruption starting from a dose of $50 \mu \mathrm{g} / \mathrm{mL}$. (B) AlamarBlue ${ }^{\circledR}$ assay shows a dose-dependent decrease in cell viability after $\mathrm{ZnO} N P$ treatment in MRC5 cells. (C) Flow cytometry (FACS) cell cycle analysis of MRC5 cells following ZnO NP exposure. Graphical representations of \% of cells on the y-axis show a significant dosedependent increase in cell death (sub-GI phase) and decrease in cell proliferation (S + G2/M phase) when treated with ZnO NPs in MRC5 cells. (D) Detection of apoptotic cells in $\mathrm{ZnO} N \mathrm{NP}$-treated MRC5 using Annexin V FITC/propidium iodide staining as analyzed by FACS. Error bars $=\mathrm{SEM}$; $* P<0.05 ; * * P<0.0 \mathrm{I} ; * * * P<0.00 \mathrm{I} ; * * * * P<0.000 \mathrm{I}$. Abbreviations: FACS, fluorescence-activated cell sorting; FITC, fluorescein isothiocyanate; LDH, lactate dehydrogenase; NPs, nanoparticles; SEM, standard error of the mean. 

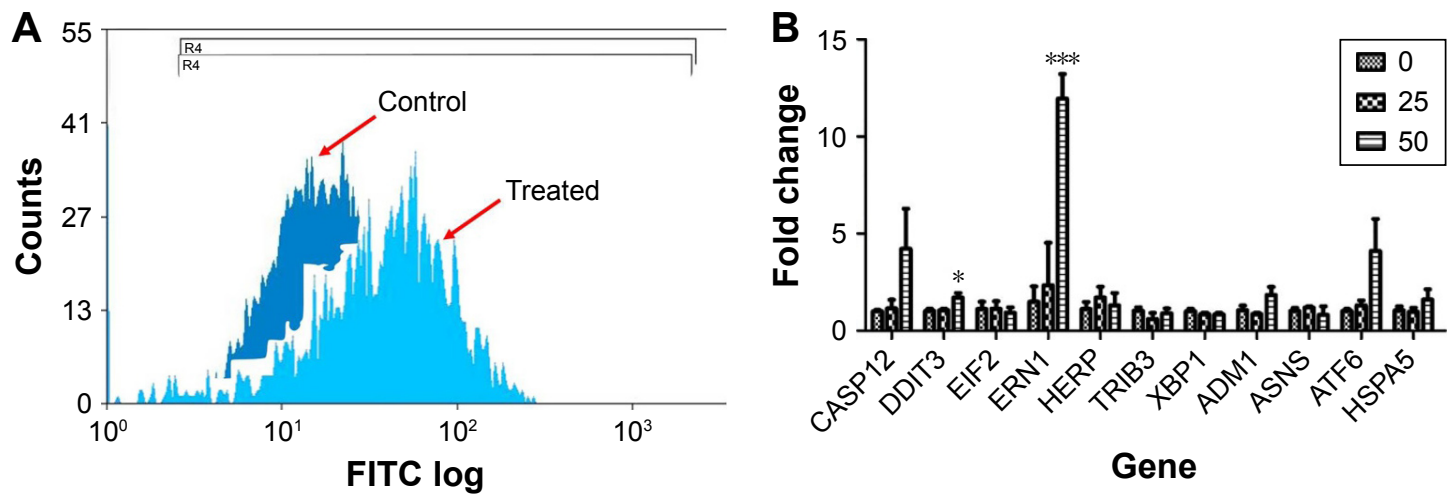

Figure $4 \mathrm{ZnO}$ NP treatment causes a significant induction of intracellular ROS in MRC5 cells.

Notes: (A) ROS generation induced by $50 \mu \mathrm{g} / \mathrm{mL} \mathrm{ZnO}$ NPs treatment as measured by FACS. There was an increase in DCFDA fluorescence intensity as indicated by a right shift in the treated cells as compared to the control cells. (B) Real time PCR analysis shows an increasing trend in the expression of ER stress-related genes in MRC5 lung fibroblasts following $16 \mathrm{~h}$ treatment at 25 and $50 \mu \mathrm{g} / \mathrm{mL}$ of $\mathrm{ZnO} N P$ s. Error bars $=\mathrm{SEM} ; * \mathrm{P}<0.05 ; * * * P<0.00 \mathrm{I}$.

Abbreviations: DCFDA, 2',7'-dichlorofluorescin diacetate; ER, endoplasmic reticulum; FACS, fluorescence-activated cell sorting; FITC, fluorescein isothiocyanate; NPs, nanoparticles; PCR, polymerase chain reaction; ROS, reactive oxygen species; SEM, standard error of the mean.

ROS levels. ROS levels in the cells exposed to ZnO NPs were found to be higher than control cells as revealed by FACS (Figure 4A). Increased ROS have been reported to be closely associated with an increase in the expression of ER-related stress response genes. ${ }^{36}$ Hence we next carried out gene expression profiling to examine the ER-related stress response in $\mathrm{ZnO}$ NP-treated cells. Of the 10 ER stressrelated genes screened, the expression of DNA damage inducible transcript 3 (DDIT3) and ER to nucleus signaling 1 (ERN1) was found to be significantly upregulated, while the rest showed a general upward expression in comparison to control cells (Figure 4B). To assess whether antioxidants can suppress $\mathrm{ZnO}$ NP-induced cell death, we pretreated the cells with LA at $300 \mu \mathrm{M}$ or GSH at $3 \mathrm{mM}$ for $24 \mathrm{~h}$. Both LA and GSH partially protected MRC5 cells against ZnO NPinduced cytotoxicity, as evidenced by the reduced amount of LDH being released (Figure S1). These results suggest that the $\mathrm{ZnO}$ NP-mediated cytotoxicity observed earlier was associated with increased ROS production.

\section{Genotoxicity}

$8-\mathrm{OHdG}$ is a nucleoside of DNA that is produced after oxidation. As ROS can cause oxidative damage to DNA, lipid and proteins, $8-\mathrm{OHdG}$ has been emerged as a reliable marker for oxidative stress. ${ }^{37}$ In this study, we found that $\mathrm{ZnO}$ NP exposure results in ROS production, leading to an accumulation of 8-OHdG (Figure 5A) followed by oxidative DNA damage as shown by the comet assay (Figure 5B). Therefore, we concluded that DNA oxidation is induced by ROS in the cells exposed to ZnO NPs. Increased DNA damage as indicated by the migration of DNA away from nucleus and the formation of a shape resembling a comet
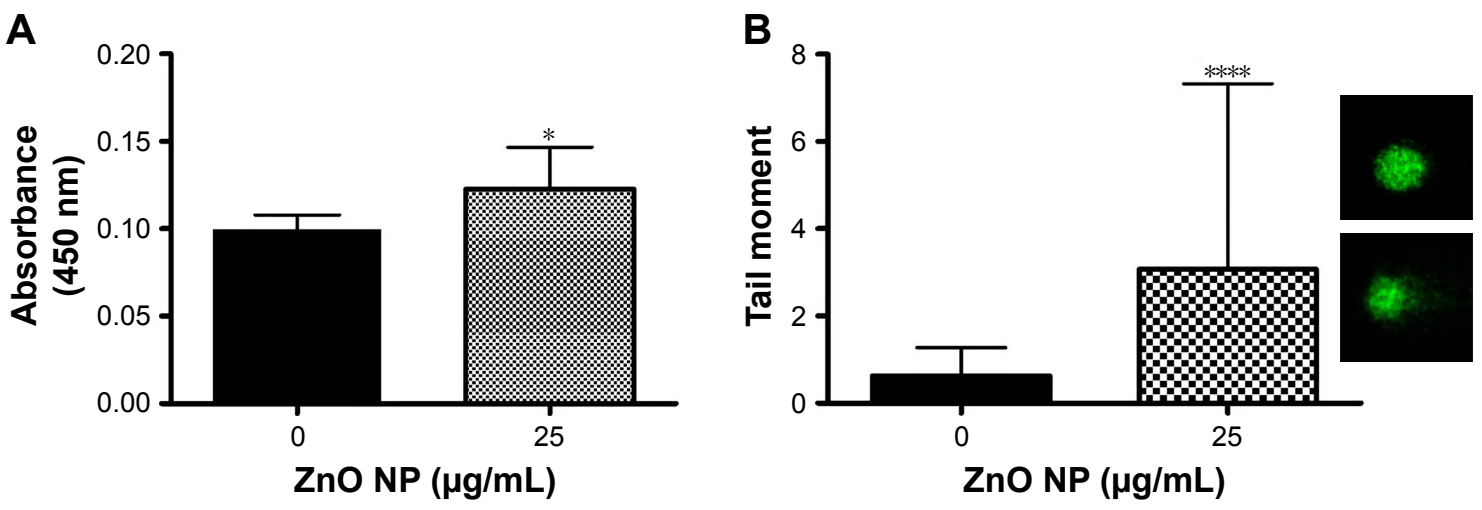

Figure 5 ZnO NPs induce genotoxicity in MRC5 cells.

Notes: (A) DNA oxidation product, 8-hydroxy-2'-deoxyguanosine (8-OHdG) was significantly increased in response to ZnO NP treatment, indicates DNA damage resulting from oxidative stress. (B) Comet assay of ZnO NP-treated MRC5 cells (bottom right inset) shows the formation of comet tail, an indicator of DNA damage, compared with control untreated cells (upper right inset; magnification: $\times 200$ ). Error bars $=S E M ; * P<0.05 ; * * * * P<0.00 I$.

Abbreviations: NPs, nanoparticles; SEM, standard error of the mean. 
tail was observed in $\mathrm{ZnO}$ NP-treated cells. The increase in oxidative DNA damage products and DNA strand breaks has verified that $\mathrm{ZnO}$ NPs elicit DNA damage.

\section{Larval uptake of NPs in the fruit fly Drosophila}

The fruit fly $D$. melanogaster has been used as an excellent in vivo model to study the toxicity of NPs. ${ }^{38}$ Since our in vitro studies using the human lung MRC5 cells showed that $\mathrm{ZnO}$ NP exposure can trigger cell death, we decided to confirm this finding using Drosophila as an in vivo model organism. Adult flies were fed $\mathrm{ZnO}$ NPs at a wide variety of concentrations by the ingestion. The distribution and localization of $\mathrm{ZnO} N P$ s in the gut of third instar larvae of F1 progenies were first examined by electron microscope after ultrathin sectioning. ZnO NPs were found to be ingested and internalized into the midgut of treated larvae. Some $\mathrm{ZnO}$ NPs were detected to be attached to microvilli in the intestinal lumen and some were observed to be enclosed inside vesicles in the cytoplasm of midgut cells, as opposed to control untreated larval midgut (Figure 6A and B).

\section{Exposure of ZnO NPs induces a decrease in the viability of Drosophila}

Canton- $S$ flies were utilized for the viability assay and administered by feeding $\mathrm{ZnO}$ NPs at various concentrations, ranging from 0 to $10 \mathrm{mg} / \mathrm{mL}$. A decrease in egg-to-adult viability of $\mathrm{F} 1$ progenies was observed in a dose-dependent manner, where only $49.8 \%$ of $\mathrm{ZnO}$ NP-exposed eggs managed to reach the adult stage successfully at the dose of $0.5 \mathrm{mg} / \mathrm{mL}$ (Figure 6C). In addition to the reduction of viability, treatment of ZnO NPs also resulted in a delay in the developmental process of Drosophila. Flies exposed to $\mathrm{ZnO}$ NPs at concentrations such as 1 or $2.5 \mathrm{mg} / \mathrm{mL}$, showed a significantly delayed eclosion compared to those exposed to $0 \mathrm{mg} / \mathrm{L} \mathrm{ZnO} \mathrm{NPs} \mathrm{(Figure} \mathrm{6D).} \mathrm{Notably,} \mathrm{these} \mathrm{results} \mathrm{are} \mathrm{in}$ contrast to an earlier study, by another group of investigators where no toxicity was found in flies treated with $50-80 \mathrm{~nm}$ $\mathrm{ZnO}$ NPs from a different commercial source. ${ }^{21}$ In an attempt to address this discrepancy, a viability study was conducted using $\mathrm{ZnO}$ NPs from two different sources. While $\mathrm{ZnO}$ NPs used in this study (at doses of 0.5 and $1 \mathrm{mg} / \mathrm{mL}$ ) were found
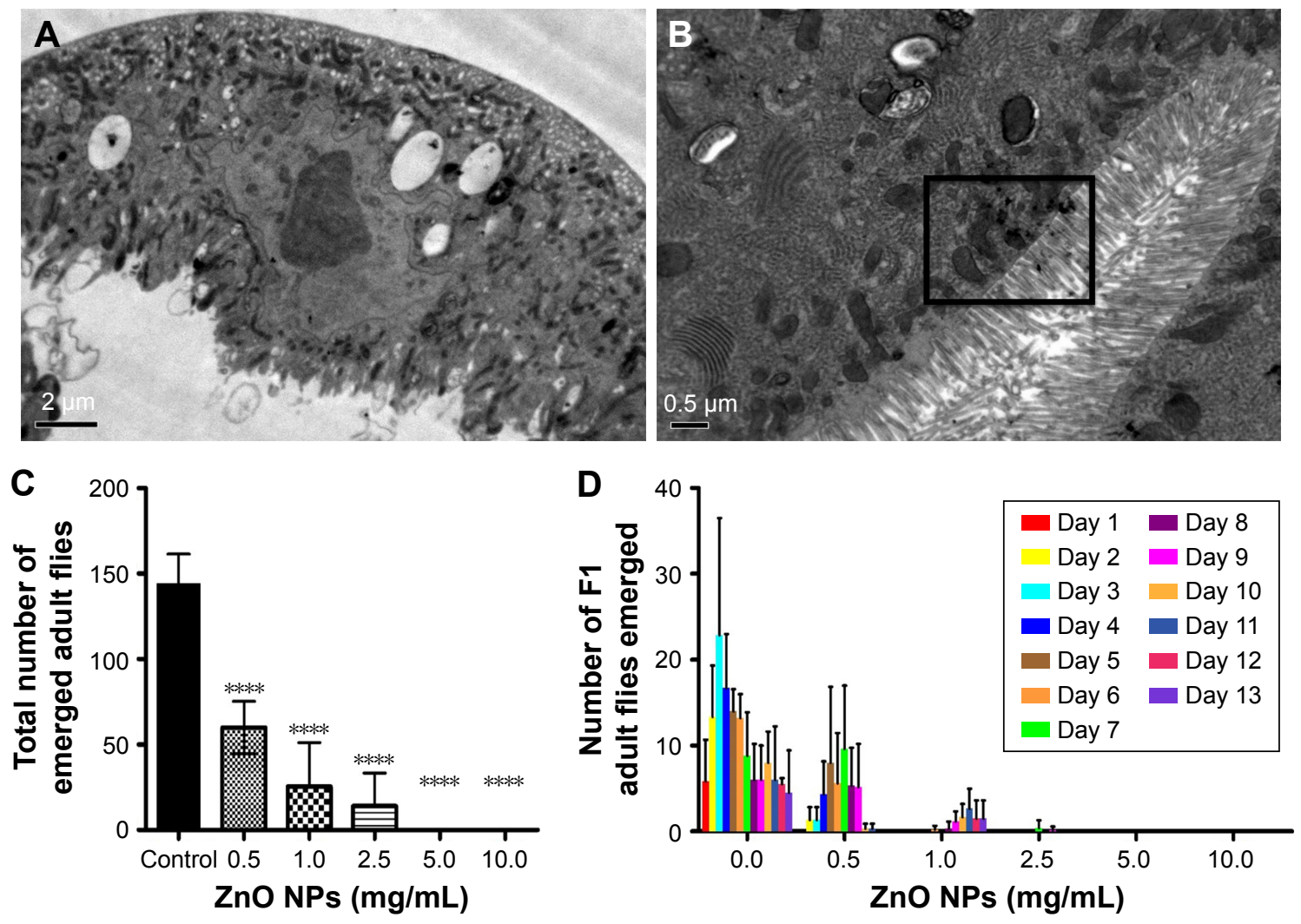

Figure $6 \mathrm{ZnO}$ NPs adversely affect the viability of the fruit fly Drosophila melanogaster.

Notes: (A) EM imaging of the intestinal lumen control larva. (B) EM imaging on larval uptake of ZnO NPs at the intestinal lumen. Presence of ZnO NPs is indicated by the boxed area. (C) Treatment of wild-type flies with ZnO NPs results in a significant decrease in viability. Wild-type flies fed with different doses of ZnO NPs were removed after 5 days upon ingestion of $\mathrm{ZnO}$ NPs. Successfully, enclosed $\mathrm{FI}$ adult flies were counted and their survival rate was presented after following up for 9 days. $* * * * P<0.000 \mathrm{I}$. (D) Treatment of wild-type flies with ZnO NPs results in a delay in development. Error bars = standard error of mean.

Abbreviations: EM, electron microscope; NPs, nanoparticles. 
to be toxic, no obvious toxicity was observed in flies treated with ZnO NPs from another source that was in agreement with the published findings (Figure S2A and B). ${ }^{21}$

\section{$\mathrm{ZnO} N P s$ induce oxidative stress in Drosophila}

It is conceivable that aberrant ROS levels induced by $\mathrm{ZnO}$ NPs affected the viability of flies. DHE, which readily reacts with superoxide anions to form 2-hydroxyethidium, thereby, generating red fluorescence, ${ }^{39}$ was used to examine ROS levels in the guts of 3rd instar larvae, following the ingestion of $\mathrm{ZnO}$ NPs. In the control gut cells, the basal amounts of ROS were detected, and the intensity observed in the control set was set as a minimum threshold (Figure 7A). On the other hand, intermediate levels of ROS were observed in the gut cells harvested from larvae fed with $0.25 \mathrm{mg} / \mathrm{mL}$ of $\mathrm{ZnO}$ NPs (Figure 7B). However, the gut cells of $0.5 \mathrm{mg} / \mathrm{mL} \mathrm{ZnO}$ NP-treated larvae showed a dramatic increase in the levels of ROS, with the highest fluorescence intensity observed (Figure 7C). This finding suggests that ZnO NP treatment induced excessive amounts of ROS, leading to a decrease in viability in vivo.

\section{Nrf2 involves in ZnO NP-induced ROS production}

To demonstrate that the decreased viability in $\mathrm{ZnO}$ NPtreated flies was at least partly due to oxidative stress, we examined the effects of loss of function of $\mathrm{Nrf} 2$ on $\mathrm{ZnO} \mathrm{NP}$ induced toxicity. Nrf2 plays as an important cellular sensor for oxidative stress. ${ }^{40,41} \mathrm{Nrf} 2$ is a transcription factor involved
A

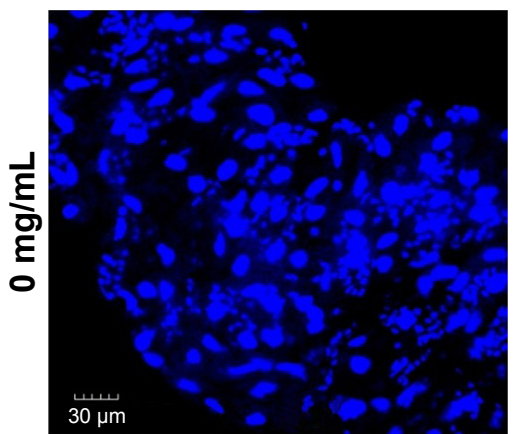

B
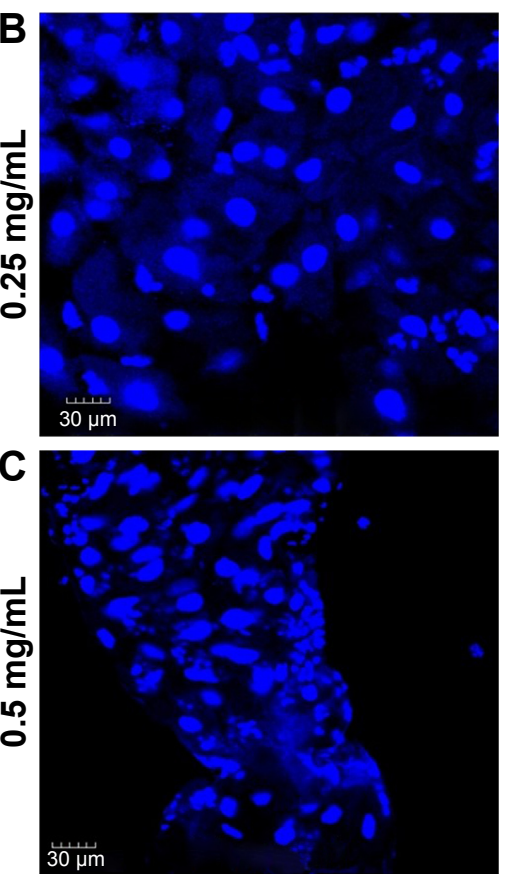

DHE
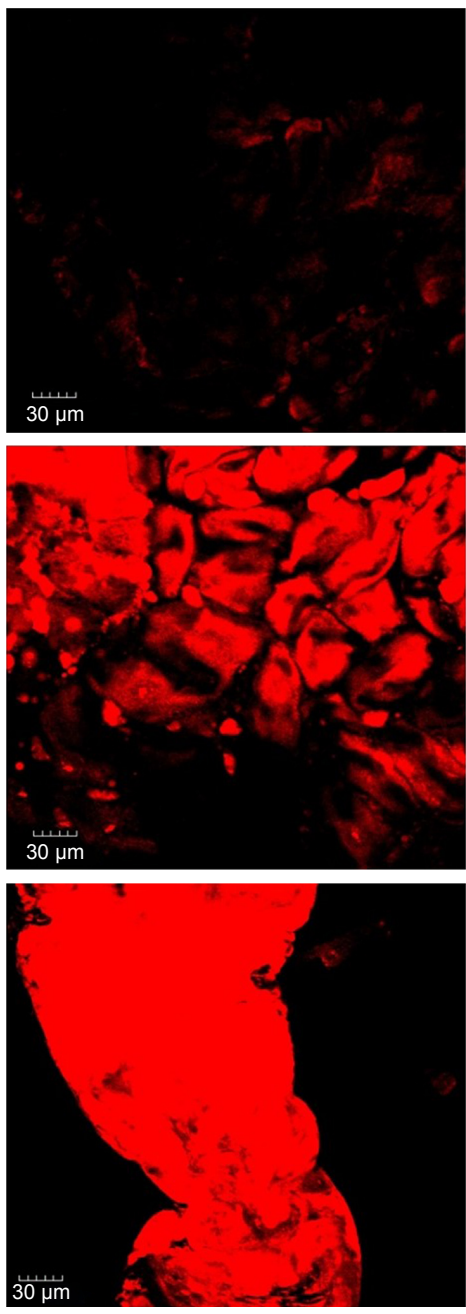

Merged
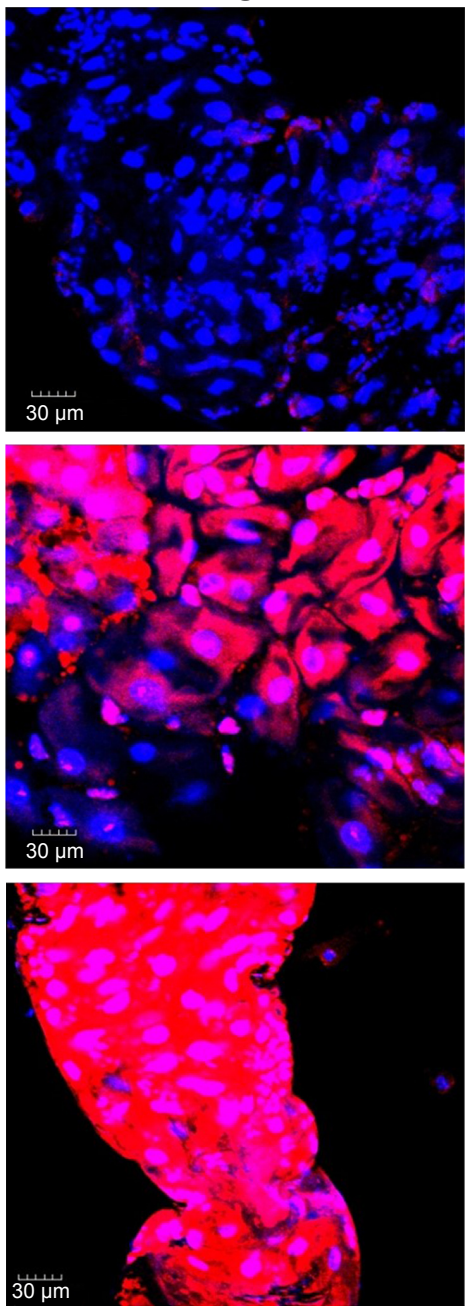

Figure $7 \mathrm{ZnO}$ NPs induce ROS in a dose-dependent manner in the midgut of the Drosophila melanogaster larvae.

Notes: (A) DHE stain in control gut shows the basal level of ROS. (B, C) Treated gut cells show a gradual increase in DHE intensity. In particular, a dramatic increase in ROS is detected in gut cells treated with ZnO NPs at $0.5 \mathrm{mg} / \mathrm{mL}$.

Abbreviations: DAPI, 4',6-diamidino-2-phenylindole; DHE, dihydroethidium; ROS, reactive oxygen species; NPs, nanoparticles. 


\section{A}
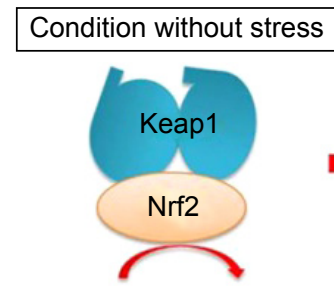

Degradation of Nrf2

Ubiquitination
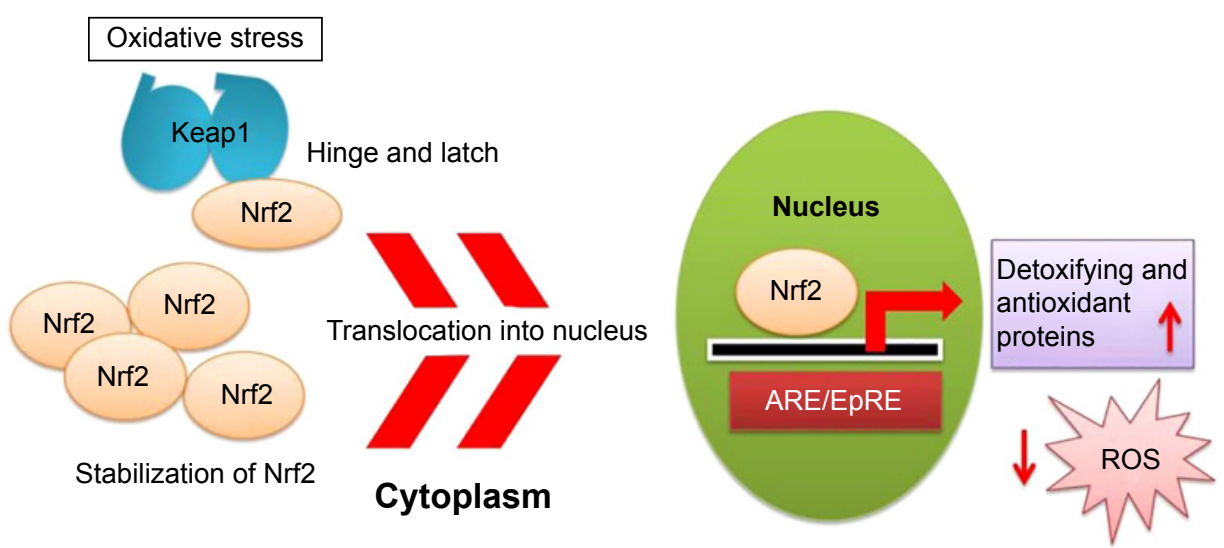

B

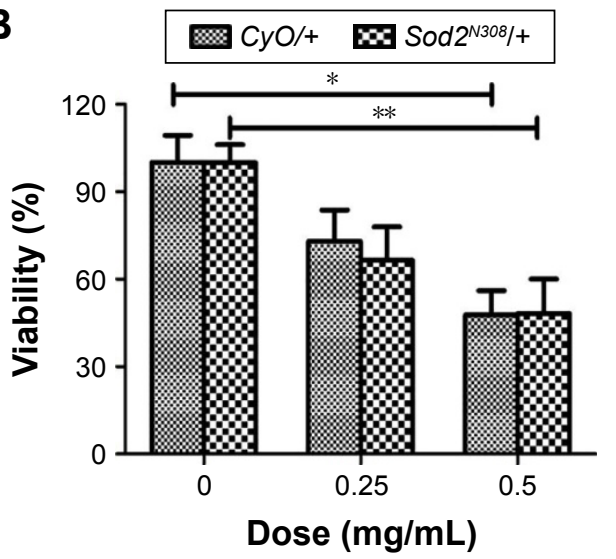

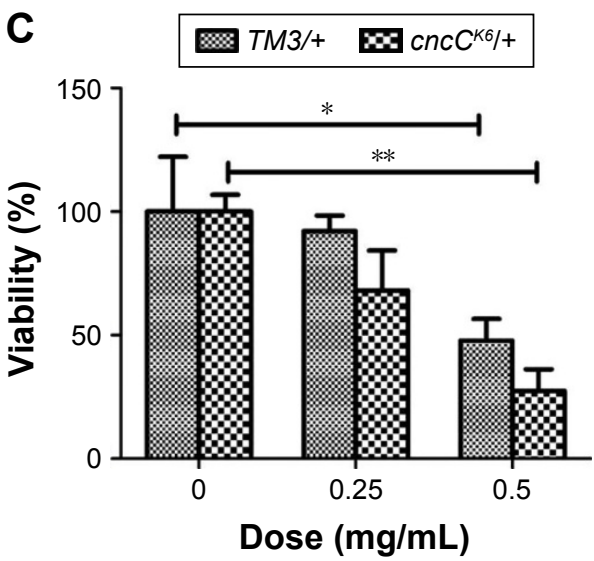

Figure 8 ROS induction is a direct cause of ZnO NP-mediated toxicity in Drosophila melanogaster.

Notes: (A) Schematic diagram showing the role of Nrf2 in the antioxidant defense mechanism. (B) Removal of one copy of Sod2 increases the lethality caused by ZnO NP treatment. (C) Removal of one copy of $\mathrm{cncC}$ (the Drosophila homolog of Nrf2) further enhanced reduction of viability caused by ZnO NP treatment. These observations suggest that excessive amounts of ROS induced by $\mathrm{ZnO}$ NPs adversely affect the viability of organisms in vivo. $* P<0.05 ; * * P<0.01$.

Abbreviations: ROS, reactive oxygen species; NPs, nanoparticles.

in the cellular response to oxidative and electrophilic stress. ${ }^{42}$ It is normally negatively regulated by its cytoplasmic effector Keap $1 .{ }^{43}$ However, upon stimulation by oxidants or electrophilic insults it is rapidly activated by protein stabilization, involving gene expression via antioxidant response element, which is a cis-acting regulatory enhancer element at the $5^{\prime}$ flanking region of many phase II enzymes that are involved in detoxification (Figure 8A) ${ }^{42,44}$ Thus, we posited that $\mathrm{ZnO}$ NP-mediated cytotoxicity would be even more severe when the activity of Nrf2 or detoxifying enzyme such as SOD2 is downregulated. As expected, the reduced viability was further enhanced in flies heterozygous for $\mathrm{Sod} 2$ or $\mathrm{CncC}$ (the Drosophila homolog of Nrf2) compared to control files (Figure 8B and C).

\section{Discussion}

The solubility of ZnO NPs is the pivotal factor in causing cytotoxicity in vitro. $\mathrm{Zn}^{2+}$ at a low concentration is essential for maintaining the cellular processes and metabolism; however, $\mathrm{Zn}^{2+}$ at a high concentration can cause toxicity. ${ }^{45}$ It has been previously reported that the dissolution of metal oxide NPs greatly influences its toxicity in vitro. ${ }^{46}$ To confirm that the dissolved $\mathrm{Zn}$ ions contribute to the observed toxicity of ZnO NPs, we performed MTS study to compare the toxicity 
of $\mathrm{Zn}$ ions and $\mathrm{ZnO}$ NPs. We found that $\mathrm{Zn}$ ions cause more toxicity to the cells than their corresponding NP counterparts (data not shown). This result further confirmed that $\mathrm{Zn}$ ions play an essential role in the toxicity of $\mathrm{ZnO}$ NPs. Several studies have also shown that the toxicity of $\mathrm{ZnO}$ NPs is due to the dissolution of the $\mathrm{ZnO}$ NPs, forming $\mathrm{Zn}^{2+}$ ions. ${ }^{47-49}$ The presence of excessive $\mathrm{Zn}^{2+}$ in the medium can disturb the ionic balance in the cells, and thus cause an ion transport inhibition and amino acid metabolism disruption. ${ }^{50}$

Other than $\mathrm{Zn}^{2+}$-induced damages, the excessive level of ROS is known to affect membrane potential change, induce lipid peroxidation, affect lipoprotein structure and cause plasma membrane injuries. The destruction of membrane functions and properties leads to cell death. ${ }^{51} \mathrm{ZnO}$ NPs exerted significant toxic effects on MRC5 cells by causing apoptotic cell death. Although the mechanism of $\mathrm{ZnO}$ NPs causing cytotoxicity is not yet fully understood, $\mathrm{ZnO}$ NPs-induced ROS are considered to be one of the main causes. When the oxidative stress exceeds the antioxidant ability of the cell, oxidative damage on critical biomolecules occurs, leading to cell death. ${ }^{52-54}$ Importantly, in this study we have demonstrated that ROS are one of the direct causes of $\mathrm{ZnO}$ NP-mediated cell death in both in vitro and in vivo models.

$\mathrm{ZnO}$ NPs can induce a cell death via apoptosis through the intrinsic mitochondrial pathway. ${ }^{45,53,55} \mathrm{ZnO}$ NPs treatment in vitro has been shown to decrease mitochondrial membrane potential and conversely increase $\mathrm{Bax} / \mathrm{Bcl} 2$ ratio. ${ }^{53}$ Interestingly, our study showed that DDIT3 expression is significantly upregulated in response to ZnO NP treatment. Increased expression of DDIT3 was shown to lead to a cell cycle arrest and apoptosis. It causes a downregulation of Bcl2 protein levels and a translocation of Bax from the cytosol into the mitochondria, and transmits DDIT3 induced-death signals to the mitochondria, acting as an integrator and amplifier of the death signaling pathway. ${ }^{56,57}$ Moreover, excessive release of $\mathrm{Zn}^{2+}$ was shown to be sequestered by the mitochondrion. ${ }^{58}$ Presence of cations aids to regulate ATP synthesis and ROS production in mitochondrion. Conversely, the rapid $\mathrm{Zn}^{2+}$ influx results in a rapid decline of mitochondrial membrane potential which subsequently activates the caspase-dependent apoptosis and release of LDH. ${ }^{45}$

$E R N 1$ encodes a protein that possesses intrinsic kinase and endoribonuclease activities, which play key roles in regulating gene expression in response to ER stress. ${ }^{59}$ In mammals, when ER homeostasis is challenged, ERN1 regulates the expression of the ER quality control components required for protein folding by splicing $X b p-1 \mathrm{mRNA}$ and activates
Regulated IRE-1 Dependent Decay to reduce the demand of protein folding as the unfolded protein response. ${ }^{60}$ ERN1 was shown to be necessary and alone was sufficient in initiating apoptosis. ${ }^{61}$ It functions to increase caspase 2 (CASP2), a proapoptotic protease essential for the execution of apoptosis, thereby promoting apoptosis. Interestingly, ERN1 was found to be significantly upregulated by $>10$ fold in MRC5 fibroblasts treated with ZnO NPs (Figure 4B), suggesting the ZnO NP-mediated ER stress followed by apoptosis.

There is a growing body of research using Drosophila as an in vivo model organism to assess NP-mediated toxicity. Drosophila shows high levels of physiological similarity and gene conservation to humans. ${ }^{38,62,63}$ In addition, the signaling pathways that control developmental processes are highly conserved between Drosophila and mammals, making it a suitable and promising in vivo model for elucidating the detailed molecular mechanisms of NP-mediated toxicity. ${ }^{64}$ It was previously reported that there is no toxicity or oxidative stress induction observed in Drosophila larvae when exposed to $\mathrm{ZnO}$ NPs. ${ }^{21}$ However, we observed a significant decrease in the viability of treated F1 progenies, suggesting the toxic effects of ZnO NPs in Drosophila. Our DLS analysis showed that the hydrodynamic radius of $\mathrm{ZnO}$ NPs used in this study is $\sim 70 \mathrm{~nm}$. Interestingly, however, our analysis revealed that the hydrodynamic radius of ZnO NPs used in the study by Alaraby et al, ${ }^{21}$ is $>1 \mu \mathrm{m}$, which is far bigger than the value stated on the data sheet $(50-80 \mathrm{~nm}$; Figure S3A). The majority of the ZnO NPs were found to be agglomerated and polydispersed (polydispersity index $=1$ ). After sonication, the $\mathrm{ZnO}$ NPs were less polydispersive but still agglomerate as large particles (Figure S3B). In support of this, they also reported that the hydrodynamic radius of the $\mathrm{ZnO}$ NPs is $291.66 \mathrm{~nm}$. The difference in the NP agglomeration state, particle stability and particle size may influence the particle-biological molecule interaction and partially explain the observed differences between the two sources of NPs concerning their ability to cause toxicity in vivo.

Our EM study showed that upon ingestion by Drosophila larvae, ZnO NPs were observed to be attached to microvilli in the intestinal lumen and enclosed inside vesicles in the cytoplasm of midgut cells (Figure 6A and B). These observations are consistent with the previous report that NPs can get internalized into the intestines and hemocytes. ${ }^{21}$ Owing to the small size of ZnO NPs, hemocytes can easily distribute them into different internal organs and interact with important biomolecules. Hence, it allows them to accumulate and deposit in the organs, causing a great damage ${ }^{65}$ Furthermore, studies in other animal models have also 
revealed that $\mathrm{ZnO}$ NPs could reach various organs through the systemic circulation upon exposure, and adversely affect the liver, lungs, brain, blood and kidneys where ZnO NPs normally accumulate. ${ }^{66,67}$ In support of this, we found a dramatic decrease in the viability and a significant delay in the development of Drosophila upon $\mathrm{ZnO} \mathrm{NP}$ exposure in a dose-dependent manner. Importantly, ZnO NPs as have shown in the present and earlier studies, are able to induce ROS production, followed by the DNA fragmentation and mitochondrial damage of the cells, in both animal systems and cultured mammalian cell lines, suggesting that ROS induction may be one of the main causes by NP-mediated toxicity. ${ }^{12,53,55}$ In this in vivo study, we employed DHE staining to monitor the ROS levels using treated 3rd instar larval midguts, and clearly demonstrated that $\mathrm{ZnO}$ NPs can induce ROS production in a dose-dependent manner in vivo.

The transcription factor Nrf2 becomes rapidly activated upon excessive ROS, and subsequently enhances the expression of a large pool of antioxidant and phase II detoxifying genes, which function to defend against oxidative and electrophilic stress. ${ }^{42}$ In Drosophila, numerous genetic tools and reagents for the study of complex biological processes are available. In an attempt to demonstrate that oxidative stress is one of the direct causes of $\mathrm{ZnO} \mathrm{NP}$-induced toxicity and that Nrf2 plays an essential role in maintaining the redox homeostasis upon oxidative stress in Drosophila, Nrf2 activity was genetically manipulated in both control and treated F1 progenies. Interestingly, removing one copy of $c n c C$ alleles $\left(c n c C^{K \sigma}\right)$ further enhanced the phenotype of decreased viability caused by the treatment of $\mathrm{ZnO}$ NPs compared to corresponding controls, suggesting that Nrf2 activity is required for salvaging ROS-associated toxicity upon $\mathrm{ZnO}$ NP exposure by activating downstream antioxidant response. Consistently, inhibition of SOD2, which functions to catalyze the dismutation of the $\mathrm{O}^{-}$radical into either $\mathrm{O}_{2}$ or $\mathrm{H}_{2} \mathrm{O}_{2}$, also increased the toxicity caused by $\mathrm{ZnO}$ NPs at $0.25 \mathrm{mg} / \mathrm{mL}$. These findings suggest that excessive ROS production is at least in part one of the direct causes of $\mathrm{ZnO}$ NP-induced toxicity in Drosophila.

\section{Conclusion}

This study showed that ZnO NPs can cause toxicity by ER stress, cytotoxicity and genotoxicity, which are closely associated with ROS generation and inevitably lead to cell death in vitro. The in vivo study also showed that $\mathrm{ZnO}$ NPs exposure via ingestion route can cause toxicity to the organism by inducing oxidative stress, resulting in the reduced viability of Drosophila. Our results from both in vitro and in vivo investigations may help to better evaluate the adverse effects of ZnO NPs which may be the important mechanism contributing to their toxicity.

\section{Acknowledgment}

The research was funded by the National Environmental Agency, Singapore (grant R-706-002-043-490).

\section{Disclosure}

The authors report no conflicts of interest in this work.

\section{References}

1. EPA. U.S. Environmental Protection Agency. Nanotechnology White Paper; 2007. Available from: https://www.epa.gov/sites/production/ files/2015-01/documents/nanotechnology_whitepaper.pdf. Accessed October, 2016.

2. Jones N, Ray B, Ranjit KT, Manna AC. Antibacterial activity of ZnO nanoparticle suspensions on a broad spectrum of microorganisms. FEMS Microbiol Lett. 2008;279(1):71-76.

3. ReportBuyer. Global Nanomaterials Market - Segmented by Product Type, End-User Industry, and Geography - Trends and Forecasts (2015-2020); 2015. Available from: https://www.reportbuyer. com/product/3281799/global-nanometals-market-segmentedby-type-application-and-geography-2015-2020.html. Accessed Octomber, 2016.

4. ReportLinker. Nanotechnology Market Outlook 2020; 2015. Available from: http://www.reportlinker.com/p02162665/NanotechnologyMarket-Outlook.html. Accessed October, 2016.

5. Lye JC, Richards CD, Dechen K, et al. Systematic functional characterization of putative zinc transport genes and identification of zinc toxicosis phenotypes in Drosophila melanogaster. J Exp Biol. 2012; 215(Pt 18):3254-3265.

6. Kim YR, Park JI, Lee EJ, et al. Toxicity of $100 \mathrm{~nm}$ zinc oxide nanoparticles: a report of 90-day repeated oral administration in Sprague Dawley rats. Int J Nanomedicine. 2014;9(Suppl 2):109-126.

7. Xie Y, He Y, Irwin PL, Jin T, Shi X. Antibacterial activity and mechanism of action of zinc oxide nanoparticles against Campylobacter jejuni. Appl Environ Microbiol. 2011;77(7):2325-2331.

8. Colvin VL. The potential environmental impact of engineered nanomaterials. Nat Biotechnol. 2003;21(10):1166-1170.

9. De Angelis I, Barone F, Zijno A, et al. Comparative study of $\mathrm{ZnO}$ and $\mathrm{TiO}(2)$ nanoparticles: physicochemical characterisation and toxicological effects on human colon carcinoma cells. Nanotoxicology. 2013;7(8):1361-1372.

10. Johnson BM, Fraietta JA, Gracias DT, et al. Acute exposure to $\mathrm{ZnO}$ nanoparticles induces autophagic immune cell death. Nanotoxicology. 2015;9(6):737-748.

11. Singh N, Manshian B, Jenkins GJ, et al. NanoGenotoxicology: the DNA damaging potential of engineered nanomaterials. Biomaterials. 2009;30(23-24):3891-3914.

12. Song W, Zhang J, Guo J, et al. Role of the dissolved zinc ion and reactive oxygen species in cytotoxicity of $\mathrm{ZnO}$ nanoparticles. Toxicol Lett. 2010;199(3):389-397.

13. Wahab R, Siddiqui MA, Saquib Q, et al. $\mathrm{ZnO}$ nanoparticles induced oxidative stress and apoptosis in HepG2 and MCF-7 cancer cells and their antibacterial activity. Colloids Surf B Biointerfaces. 2014; 117:267-276.

14. Namvar F, Rahman HS, Mohamad R, et al. Cytotoxic effects of biosynthesized zinc oxide nanoparticles on murine cell lines. Evid Based Complement Alternat Med. 2015;2015:593014.

15. Wong SW, Leung PT, Djurisic AB, Leung KM. Toxicities of nano zinc oxide to five marine organisms: influences of aggregate size and ion solubility. Anal Bioanal Chem. 2010;396(2):609-618. 
16. Hsiao IL, Huang YJ. Effects of various physicochemical characteristics on the toxicities of $\mathrm{ZnO}$ and $\mathrm{TiO}$ nanoparticles toward human lung epithelial cells. Sci Total Environ. 2011;409(7):1219-1228.

17. Lee J, Kang BS, Hicks B, et al. The control of cell adhesion and viability by zinc oxide nanorods. Biomaterials. 2008;29(27):3743-3749.

18. Asati A, Santra S, Kaittanis C, Perez JM. Surface-charge-dependent cell localization and cytotoxicity of cerium oxide nanoparticles. ACS Nano. 2010;4(9):5321-5331.

19. Hua J, Vijver MG, Richardson MK, Ahmad F, Peijnenburg WJ. Particlespecific toxic effects of differently shaped zinc oxide nanoparticles to zebrafish embryos (Danio rerio). Environ Toxicol Chem. 2014; 33(12):2859-2868.

20. Zhao X, Wang S, Wu Y, You H, Lv L. Acute ZnO nanoparticles exposure induces developmental toxicity, oxidative stress and DNA damage in embryo-larval zebrafish. Aquat Toxicol. 2013;136-137:49-59.

21. Alaraby M, Annangi B, Hernandez A, Creus A, Marcos R. A comprehensive study of the harmful effects of $\mathrm{ZnO}$ nanoparticles using Drosophila melanogaster as an in vivo model. J Hazard Mater. 2015; 296:166-174.

22. Wan R, Mo Y, Feng L, Chien S, Tollerud DJ, Zhang Q. DNA damage caused by metal nanoparticles: involvement of oxidative stress and activation of ATM. Chem Res Toxicol. 2012;25(7):1402-1411.

23. Demir E, Creus A, Marcos R. Genotoxicity and DNA repair processes of zinc oxide nanoparticles. J Toxicol Environ Health A. 2014;77(21): $1292-1303$.

24. Osman IF, Baumgartner A, Cemeli E, Fletcher JN, Anderson D. Genotoxicity and cytotoxicity of zinc oxide and titanium dioxide in HEp-2 cells. Nanomedicine (Lond). 2010;5(8):1193-1203.

25. Sharma V, Shukla RK, Saxena N, Parmar D, Das M, Dhawan A. DNA damaging potential of zinc oxide nanoparticles in human epidermal cells. Toxicol Lett. 2009;185(3):211-218.

26. Sharma V, Singh SK, Anderson D, Tobin DJ, Dhawan A. Zinc oxide nanoparticle induced genotoxicity in primary human epidermal keratinocytes. J Nanosci Nanotechnol. 2011;11(5):3782-3788.

27. Beckett WS, Chalupa DF, Pauly-Brown A, et al. Comparing inhaled ultrafine versus fine zinc oxide particles in healthy adults: a human inhalation study. Am J Respir Crit Care Med. 2005;171(10):1129-1135.

28. Adamcakova-Dodd A, Stebounova LV, Kim JS, et al. Toxicity assessment of zinc oxide nanoparticles using sub-acute and sub-chronic murine inhalation models. Part Fibre Toxicol. 2014;11:15.

29. Colon G, Ward BC, Webster TJ. Increased osteoblast and decreased Staphylococcus epidermidis functions on nanophase $\mathrm{ZnO}$ and $\mathrm{TiO} 2$. J Biomed Mater Res A. 2006;78(3):595-604.

30. Ryu HJ, Seo MY, Jung SK, et al. Zinc oxide nanoparticles: a 90-day repeated-dose dermal toxicity study in rats. Int J Nanomedicine. 2014; 9(Suppl 2):137-144.

31. Carmona ER, Inostroza-Blancheteau C, Rubio L, Marcos R. Genotoxic and oxidative stress potential of nanosized and bulk zinc oxide particles in Drosophila melanogaster. Toxicol Ind Health. 2016;32(12):1987-2001.

32. Bakand S, Hayes A, Dechsakulthorn F. Nanoparticles: a review of particle toxicology following inhalation exposure. Inhal Toxicol. 2012; 24(2):125-135.

33. Deng H, Kerppola TK. Visualization of the Drosophila dKeap1-CncC interaction on chromatin illumines cooperative, xenobiotic-specific gene activation. Development. 2014;141(16):3277-3288.

34. Kong L, Gao X, Zhu J, Cheng K, Tang M. Mechanisms involved in reproductive toxicity caused by nickel nanoparticle in female rats. Environ Toxicol. 2016;31(11):1674-1683.

35. Saini P, Saha SK, Roy P, Chowdhury P, Sinha Babu SP. Evidence of reactive oxygen species (ROS) mediated apoptosis in Setaria cervi induced by green silver nanoparticles from Acacia auriculiformis at a very low dose. Exp Parasitol. 2016;160:39-48.

36. Lee HM, Kim CW, Hwang KA, Choi DW, Choi KC. Three components of cigarette smoke altered the growth and apoptosis of metastatic colon cancer cells via inducing the synthesis of reactive oxygen species and endoplasmic reticulum stress. Environ Toxicol Pharmacol. 2016;45:80-89.
37. Wu LL, Chiou CC, Chang PY, Wu JT. Urinary 8-OHdG: a marker of oxidative stress to DNA and a risk factor for cancer, atherosclerosis and diabetics. Clin Chim Acta. 2004;339(1-2):1-9.

38. Ong C, Yung LY, Cai Y, Bay BH, Baeg GH. Drosophila melanogaster as a model organism to study nanotoxicity. Nanotoxicology. 2015;9(3): 396-403.

39. Kalyanaraman B, Darley-Usmar V, Davies KJ, et al. Measuring reactive oxygen and nitrogen species with fluorescent probes: challenges and limitations. Free Radic Biol Med. 2012;52(1):1-6.

40. Bryan HK, Olayanju A, Goldring CE, Park BK. The Nrf2 cell defence pathway: Keap1-dependent and -independent mechanisms of regulation. Biochem Pharmacol. 2013;85(6):705-717.

41. Davies TG, Wixted WE, Coyle JE, et al. Monoacidic inhibitors of the Kelch-like ECH-associated protein 1: nuclear factor erythroid 2-related factor 2 (KEAP1:NRF2) protein-protein interaction with high cell potency identified by fragment-based discovery. J Med Chem. 2016;59(8):3991-4006.

42. Liu Y, Kern JT, Walker JR, Johnson JA, Schultz PG, Luesch H. A genomic screen for activators of the antioxidant response element. Proc Natl Acad Sci U S A. 2007;104(12):5205-5210.

43. Itoh K, Wakabayashi N, Katoh Y, et al. Keap1 represses nuclear activation of antioxidant responsive elements by Nrf2 through binding to the amino-terminal Neh2 domain. Genes Dev. 1999;13(1):76-86.

44. Nguyen T, Sherratt PJ, Huang HC, Yang CS, Pickett CB. Increased protein stability as a mechanism that enhances Nrf2-mediated transcriptional activation of the antioxidant response element. Degradation of Nrf2 by the 26 S proteasome. J Biol Chem. 2003;278:4536-4541.

45. Kao YY, Chen YC, Cheng TJ, Chiung YM, Liu PS. Zinc oxide nanoparticles interfere with zinc ion homeostasis to cause cytotoxicity. Toxicol Sci. 2012;125(2):462-472.

46. Brunner TJ, Wick P, Manser P, et al. In vitro cytotoxicity of oxide nanoparticles: comparison to asbestos, silica, and the effect of particle solubility. Environ Sci Technol. 2006;40(14):4374-4381.

47. Franklin NM, Rogers NJ, Apte SC, Batley GE, Gadd GE, Casey PS. Comparative toxicity of nanoparticulate $\mathrm{ZnO}$, bulk $\mathrm{ZnO}$, and $\mathrm{ZnCl} 2$ to a freshwater microalga (Pseudokirchneriella subcapitata): the importance of particle solubility. Environ Sci Technol. 2007;41(24):8484-8490.

48. Heinlaan M, Ivask A, Blinova I, Dubourguier HC, Kahru A. Toxicity of nanosized and bulk $\mathrm{ZnO}, \mathrm{CuO}$ and $\mathrm{TiO} 2$ to bacteria Vibrio fischeri and crustaceans Daphnia magna and Thamnocephalus platyurus. Chemosphere. 2008;71(7):1308-1316.

49. Ma H, Bertsch PM, Glenn TC, Kabengi NJ, Williams PL. Toxicity of manufactured zinc oxide nanoparticles in the nematode Caenorhabditis elegans. Environ Toxicol Chem. 2009;28(6):1324-1330.

50. Sirelkhatim A, Mahmud S, Seeni A, et al. Review on zinc oxide nanoparticles: antibacterial activity and toxicity mechanism. Nano-Micro Letters. 2015;7(3):219-242.

51. Stark G. Functional consequences of oxidative membrane damage. J Membr Biol. 2005;205(1):1-16.

52. Ryu W, Park Y, Bae HC, et al. ZnO nanoparticle induces apoptosis by ROS triggered mitochondrial pathway in human keratinocytes. Mol Cell Toxicol. 2014;10(4):387-391.

53. Sharma V, Anderson D, Dhawan A. Zinc oxide nanoparticles induce oxidative DNA damage and ROS-triggered mitochondria mediated apoptosis in human liver cells (HepG2). Apoptosis. 2012;17(8):852-870.

54. Yu KN, Yoon TJ, Minai-Tehrani A, et al. Zinc oxide nanoparticle induced autophagic cell death and mitochondrial damage via reactive oxygen species generation. Toxicol In Vitro. 2013;27(4):1187-1195.

55. Guo D, Bi H, Liu B, Wu Q, Wang D, Cui Y. Reactive oxygen speciesinduced cytotoxic effects of zinc oxide nanoparticles in rat retinal ganglion cells. Toxicol In Vitro. 2013;27(2):731-738.

56. McCullough KD, Martindale JL, Klotz LO, Aw TY, Holbrook NJ. Gadd153 sensitizes cells to endoplasmic reticulum stress by downregulating Bcl2 and perturbing the cellular redox state. Mol Cell Biol. 2001;21(4):1249-1259.

57. Oyadomari S, Koizumi A, Takeda K, et al. Targeted disruption of the Chop gene delays endoplasmic reticulum stress-mediated diabetes. J Clin Invest. 2002;109(4):525-532. 
58. Sensi SL, Ton-That D, Sullivan PG, et al. Modulation of mitochondrial function by endogenous Zn2+ pools. Proc Natl Acad Sci US A. 2003;100(10):6157-6162.

59. Shore GC, Papa FR, Oakes SA. Signaling cell death from the endoplasmic reticulum stress response. Curr Opin Cell Biol. 2011;23(2):143-149.

60. Han D, Lerner AG, Vande Walle L, et al. IRE1alpha kinase activation modes control alternate endoribonuclease outputs to determine divergent cell fates. Cell. 2009;138(3):562-575.

61. Upton JP, Wang L, Han D, et al. IRE1alpha cleaves select microRNAs during ER stress to derepress translation of proapoptotic Caspase-2. Science. 2012;338(6108):818-822.

62. Ong C, Lee QY, Cai Y, et al. Silver nanoparticles disrupt germline stem cell maintenance in the Drosophila testis. Sci Rep. 2016;6:20632.
63. Vecchio G. A fruit fly in the nanoworld: once again Drosophila contributes to environment and human health. Nanotoxicology. 2015;9:135-137.

64. Apidianakis Y, Rahme LG. Drosophila melanogaster as a model for human intestinal infection and pathology. Dis Model Mech. 2011; 4(1):21-30.

65. Chang Y, Zhang M, Xia L, Zhang J, Xing G. The toxic effects and mechanisms of $\mathrm{CuO}$ and $\mathrm{ZnO}$ nanoparticles. Materials. 2012; 5(12):2850-2871

66. Li CH, Shen CC, Cheng YW, et al. Organ biodistribution, clearance, and genotoxicity of orally administered zinc oxide nanoparticles in mice. Nanotoxicology. 2012;6(7):746-756.

67. Vandebriel RJ, De Jong WH. A review of mammalian toxicity of $\mathrm{ZnO}$ nanoparticles. Nanotechnol Sci Appl. 2012;5:61-71. 


\section{Supplementary materials}
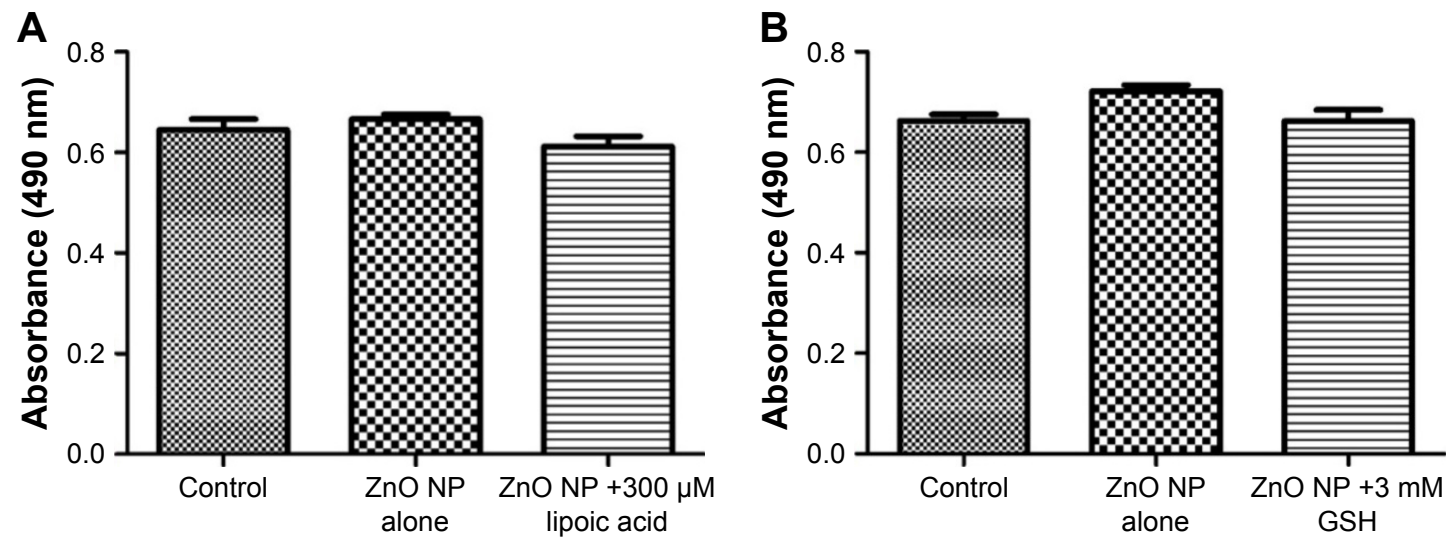

Figure SI Effect of LA and GSH on ZnO NP-induced cytotoxicity in MRC5 cells.

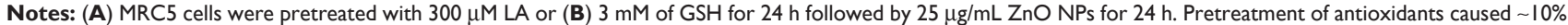
$(8.317 \% \pm 3.044 \%$ and $9.013 \% \pm 3.327 \%$, respectively) decrease in LDH compared to ZnO NPs alone.

Abbreviations: GSH, glutathione; LA, lipoic acid; LDH, lactate dehydrogenase; NPs, nanoparticles.
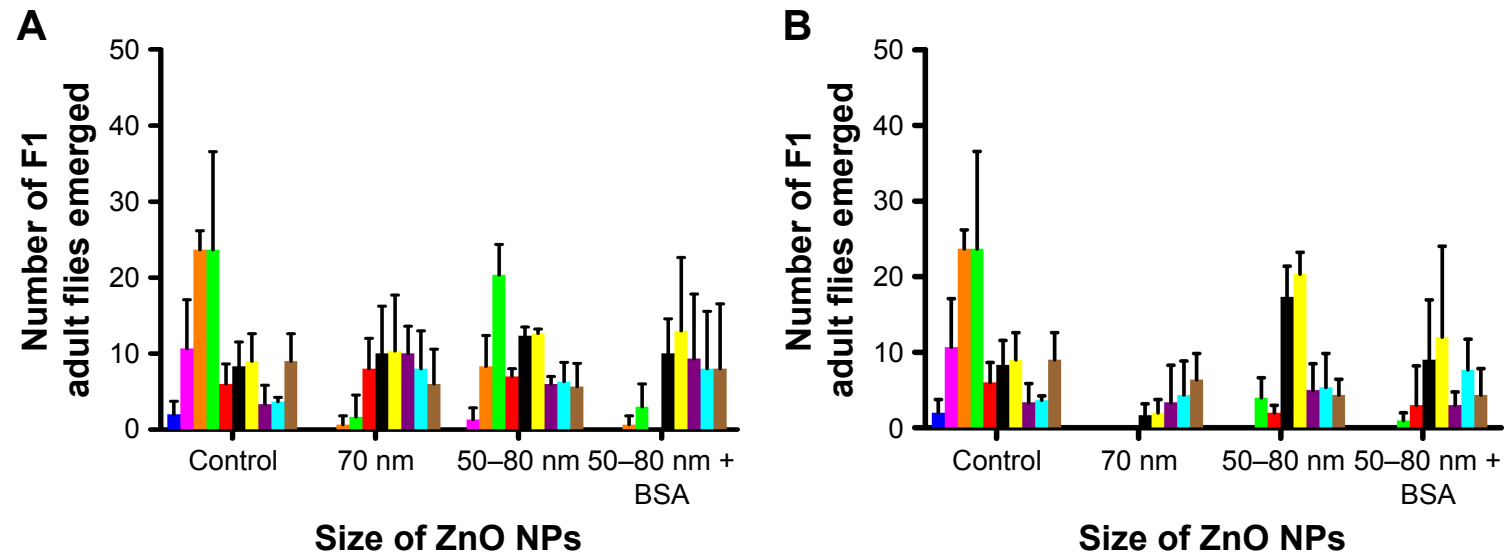

\begin{tabular}{|lrrrr|}
\hline Day 1 & Day 2 & Day 3 & Day 4 & Day 5 \\
Day 6 & Day 7 & Day 8 & Day 9 & Day 10 \\
\hline
\end{tabular}

Figure S2 Comparison of the toxicity in Drosophila fed with two different $\mathrm{ZnO}$ NPs at 0.5 and I mg/mL.

Notes: The number of emerged adult flies exposed to ZnO NPs at (A) $0.5 \mathrm{mg} / \mathrm{mL}$ or (B) I mg/mL of ZnO NPs was recorded for 10 days. While administration of $\sim 70 \mathrm{~nm}$ of $\mathrm{ZnO}$ NPs significantly reduced the viability as stated earlier on, oral administration of $50-80 \mathrm{~nm} Z \mathrm{nO}$ NPs at both doses did not affect the viability greatly. Error bars $=$ standard error of mean.

Abbreviations: BSA, bovine serum albumin; NPs, nanoparticles. 

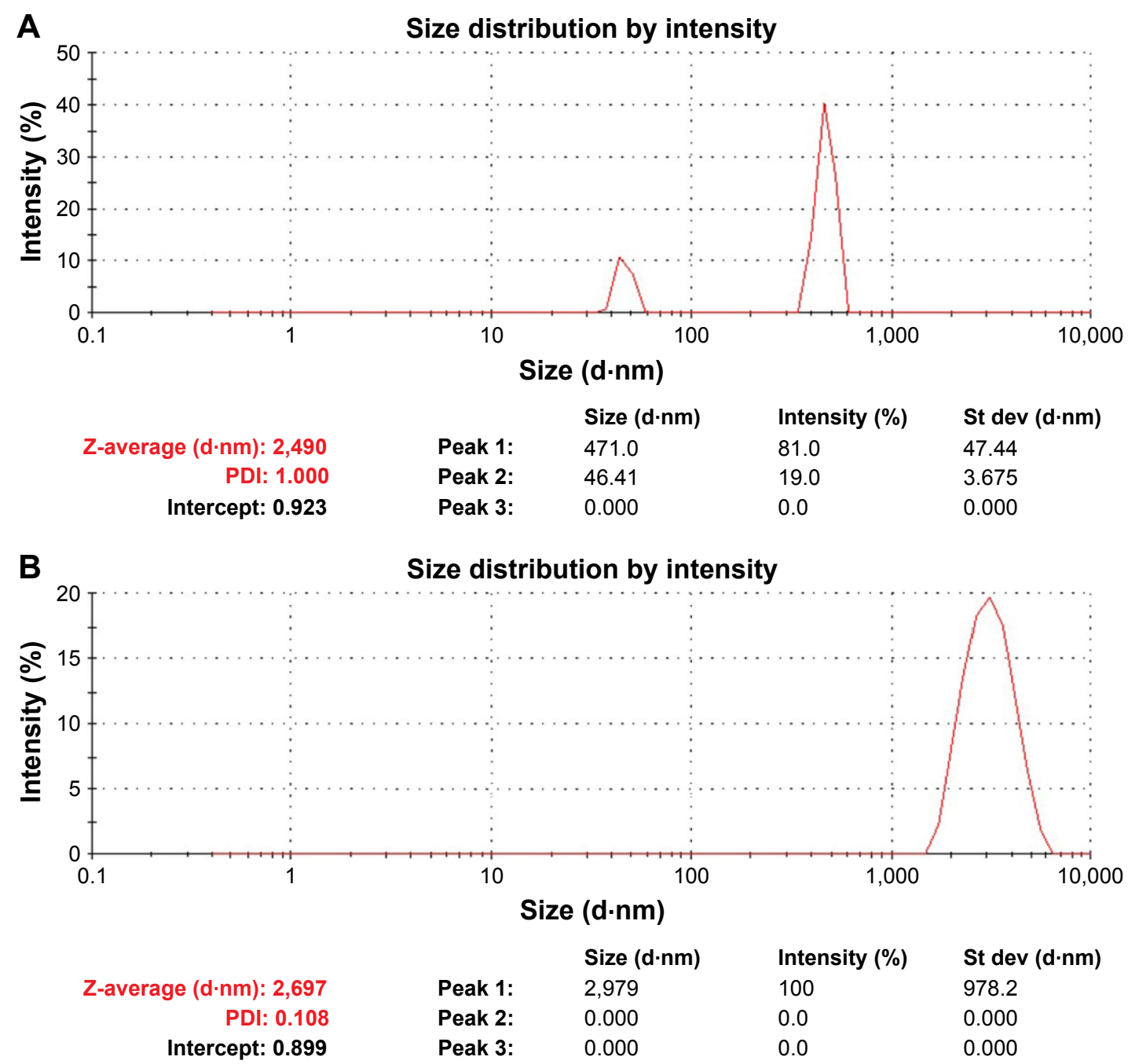

Figure S3 Particle size measurement of ZnO NPs in water by DLS technique.

Notes: (A) ZnO NPs used in the study by Alaraby et $\mathrm{a}^{21}$ before sonication showed that majority of the NPs are $>1 \mu \mathrm{m}$ and (B) after sonication, the NPs became less polydispersive although majority of the NPs still agglomerated as large particles.

Abbreviations: DLS, dynamic light scattering; NPs, nanoparticles; PDI, polydispersity index; St dev, standard deviation.

International Journal of Nanomedicine

\section{Publish your work in this journal}

The International Journal of Nanomedicine is an international, peerreviewed journal focusing on the application of nanotechnology in diagnostics, therapeutics, and drug delivery systems throughou the biomedical field. This journal is indexed on PubMed Central, MedLine, CAS, SciSearch ${ }^{\circledR}$, Current Contents ${ }^{\circledR} /$ Clinical Medicine,

\section{Dovepress}

Journal Citation Reports/Science Edition, EMBase, Scopus and the Elsevier Bibliographic databases. The manuscript management system is completely online and includes a very quick and fair peer-review system, which is all easy to use. Visit http://www.dovepress.com/ testimonials.php to read real quotes from published authors.

\footnotetext{
Submit your manuscript here: http://www.dovepress.com/international-journal-of-nanomedicine-journal
} 